\title{
Assessing Business Model For Motorcycle Rental Based Mobile Application Using Balanced Scorecard (Case Study at PT XYZ)
}

\author{
Gunawan Wang ${ }^{1}$, Tjoa Han Hwa ${ }^{2}$ \\ ${ }^{12}$ Information Systems Management Department, BINUS Graduate Program-Master of Information Systems \\ Management, Bina Nusantara University, Jakarta, Indonesia \\ ${ }^{1}$ gwang@binus.edu, ${ }^{2}$ tjoa.hwa@ binus.ac.id
}

\begin{abstract}
Using a balanced scorecard, authors conduct an in-depth assessment of the business model for motorcycle rental based mobile application. With measurements on four perspectives: financial, customer, internal business process, and learning and growth, business model assessed whether to contribute to the long-term strategy of PT XYZ. The assessment use financial plan, financial projection, financial ratio, and feasibility study in measuring the business models from a financial perspective. Use the marketing mix in measuring the business model from a customer perspective. Design organizational structure, job description, and business process models for measuring aspects of the internal business process. Also, establish a risk management plan and KPIs in a learning and growth perspective. It is concluded that the business model for motorcycle rental based mobile application can contribute to the long-term strategy of PT XYZ.
\end{abstract}

Key words: balanced scorecard; business model; motorcycle rental; mobile application

\section{INTRODUCTION}

In Indonesia, the trend of ride-sharing with the mobile app has become a new culture, seen in the rapid development of Go-Jek and Grab as competitors. The conventional rental business in Indonesia has a more significant impact. Some of Indonesia's rental companies have suffered losses. Almost all rental companies in Indonesia do not utilize the mobile application, except for the Blue Bird Taxi that joins with GoJek.

There are six domestic rental companies already listed on the Indonesia Stock Exchange (IDX): TRAC Astra Rent Car, Blue Bird, MPM Rent, ASSA Rent, Tunas Rent, and Express Transindo Utama. In 2017, TRAC suffered a decline in the number of operating vehicles by $0.6 \%$ for cars and $20 \%$ for motorcycles [1]. Blue Bird Group sustained a decrease in the 31,714 units in 2016 to 29,001 units in 2017, down $8.6 \%$ [2]. On the annual report, MPM Rent was published in revenue in 2017, declining 3\% compared to 2016 [3]. In the year 2017, the Express Group managed more than 9,200 units regular taxi and did not make additions [4]. The number of fleet Tunas Rent increased from the previous 7,730 units to 8,350 units in the year 2017 [5]. Improvements also occurred in ASSA, seen from an increase in the number of vehicles, 19,199 units in the year 2016 to 20,880 units in 2017[6]. The three rental companies decreased their performance, one stagnant, and two increased. Compared the conventional rental company, especially in ride-sharing models, a mobile application becomes a significant factor in the success of the rental business. Along with the development of smartphone technology, and the price is increasingly affordable, nowadays, mobile applications are already widely used by the people of Indonesia, even to the remote areas.

This assessment was conducted on PT. XYZ, an authorized motorcycle dealer company, which has three existing businesses: motorcycle sales, spare part sales, and motorcycle workshop. The company wants to create a new business as a supporter of the current business. Starting from the year 2018, piloting rental business has been done in Tangerang City with three-wheeled motorcycle rental, aimed to small and micro enterprises (SMEs) [8]. For a reason above, the authors are interested in using a balanced scorecard to assess the rental business model.

According to the background that has been outlined above, the problems that want to be examined are :

1. Do these motorcycle vehicle rental businesses contribute to the company's long-term strategy by assessed from a financial perspective using a balanced scorecard?

2. Do these motorcycle vehicle rental businesses contribute to the company's long-term strategies by assessed from customer perspective using balanced scorecard?

3. Will this motorcycle vehicle rental business contribute to a long-term corporate strategy by assessed from an internal business process perspective using a balanced scorecard?

4. Do these motorcycle vehicle rental businesses contribute to the company's long-term strategy by assessed from a learning and development perspective using a balanced scorecard? 


\section{LITERATURE REVIEW}

\subsection{Rental Business}

According to the Indonesia accounting and financial statement (Pernyataan Standar Akuntansi Keuangan/PSAK) No.30 revised 2007, rental or lease is an agreement whereby the lessor grants the right to the lessee to use an asset during the agreed period. Vehicle rental is a business that offers vehicle rental services to the needy, both individual and corporate. Lessee is not responsible for maintenance and repairment of the vehicles, but vehicle rental owners (lessor) are very important to keep the vehicle condition because the key to the success of vehicle rental is to keep the cost of vehicle maintenance always to be lower. In addition to being considered more practical, to get this rental vehicle is indeed relatively easy compared with buying, provided that consumers can fulfill some of the requirements specified by the company or the owner of the vehicle. Another advantage, the community does not have to bother to buy a vehicle. The components that are prepared to open a vehicle rental business in Indonesia are:

- infrastructure and facilities, such as strategic place or location, experts who are experienced enough in the vehicle rental business, adequate business capital, and licensing;

- financial planning and control: cash flow projection (do not forget to enter the cost of vehicle backup depreciation), conduct regular administration and bookkeeping such as customer data records, office inventory goods records, notes daily cash books and others, as well as income/monthly statements;

- marketing strategy planning. [9]

\subsection{Business Risk of Vehicle Rental}

The effort of the rental company to resolve the default caused by the lessee on lease agreement of vehicle rental through dispute resolution efforts outside the court of negotiations with the lessee and the request for compensation from the lessee who performs the default. Meanwhile, regarding the constraints faced by the parties in solving the problem is divided into two points of view. From the viewpoint of the vehicle rental company are the character of the lessee, lessee that delay payments, and application for an insurance claim that takes a long time. While from the point of view the vehicle lessor is: business management of the company is poor about vehicle rental, unbalanced position between the company vehicle rental with vehicle lessee, and unpredictable conditions. It is necessary that the renewal and improvement to the manuscript of the lease so that the agreement can cover the interests of the two parties so that in the implementation of the day does not harm the parties or either party [10].

\subsection{Balanced Scorecard}

To assess the performance of the company required an integrated and comprehensive performance measuring method consisting of financial and non-financial aspects. The company expects a precise performance measurement to know how well the company performs. It becomes essential for the company because, in addition to being used to assess the company's success, performance measurement can also be a tool to evaluate the past period, with the balanced scorecard [11].

The balanced scorecard (BSC) was first introduced in 1992 by Norton and Kaplan. BSC is a measurement method of performance that not only conducts an assessment of financial performance aspects also the assessment of nonfinancial aspects of performance. BSC is a method of measuring the overall performance of the company into four perspectives: financial perspective, customer perspective, internal business process perspective, and learning and growth perspective [12]. The implementation of BSC can produce two main reports the strategic map and scorecard [13]. Here are four steps to designing a scoring card management system: (1) Translate vision into operational objectives; (2) communicate the vision and link to individual or specific process performance; (3) change the cause and effect to target based on criteria; (4) have feedback, study, and adjust the appropriate strategy [14].

In its development, the balanced scorecard also transforms into an IT Balanced Scorecard which is used to determine if the information technology systems used have supported the vision, mission, and objectives of the company [13]. Grembergen and Bruggen (1997) Adjust the Balanced Scorecard (Kaplan model \& Norton) for use in information technology. They noted that the IT department was an internal service provider, so the four perspectives were adjusted to the changes that occurred. The four perspectives tailored in IT BSC are as follows: (1) corporate contribution, (2) user orientation perspective, (3) operational excellence perspectives, and (4) future orientation perspective [15].

\subsection{Marketing Mix}

The marketing mix is a mixture of variables that can be used by a company to pursue the desired level of sales in the target market. The marketing mix is essential to minimize the risk of failure and to increase the efficiency and effectiveness in marketing that aims to profit. Originally marketing mix activity classification is a 4P: product, price, place, and promotion. Later developed to services products need to be added 3P, so the marketing mix in service companies use 7P: product, place, promotion, price, people (employees including leaders), process (business process), and physical evidence. 


\subsection{Mobile Application}

With the estimation of 62.69 million users in 2017, Indonesia has become one of the largest smartphone markets in Asia. With this large number of users, the mobile application is an opportunity for many companies. These applications are used to improve operational efficiency, increase competitiveness, and meet new customer demands [16]. Application and database designed to store in public cloud storage, cloud storage where the enterprise and storage service provider are separate, and there are not any cloud resources stored in the enterprise's data center. The cloud storage provider fully manages the enterprise's public cloud storage [17]. The rental customer can make payment through mobile application. In research, majority customers perceived 'privacy and security' a critical issue [18].

\section{ASSESSMENT METHODOLOGY}

The study started from case studies in XYZ Company, an authorized motor dealer. The main business of this company is the sale of motorcycles, sale of motorcycle spare parts, and repair services (workshops). With the idea of the business development of motorcycle rental, it is expected to provide added value for this company, which is the new business model is still related to its main business. Here is a framework of thinking to assess a business model for motorcycle rental based mobile application using a balanced scorecard (see Figure 1 below).

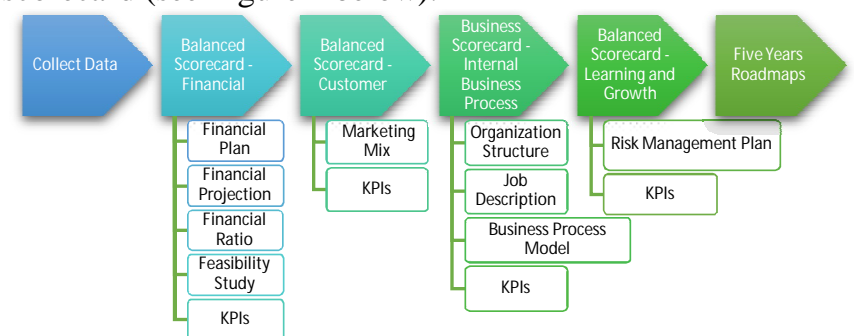

Figure 1: Assessment Method

\subsection{Balanced Scorecard}

After getting a complete picture of the company and the new business model, the next will be discussed the rental business model in four perspectives of the balanced scorecard: the financial perspective, the customer perspective, the internal business process perspective, and the learning and growth perspective. These four perspectives are related to one another, although the discussion is done sequentially.

In the financial perspective discussion, will be designed financial plan and financial projection, then measured financial ratio: the return of assets (ROA), the return of equity (ROE), the return of investment (ROI), and profit margin. The author is also doing the feasibility study: net present value (NPV), interest rate return (IRR), and payback period. Finally, determine the key performance indicators for the rental business from the financial point of views.
In the customer perspective discussion, will be designed using the marketing mix model and determine the key performance indicator from the customer angle. In the discussion of internal business process perspective, will be designed starting from organization structure for new business, the job description for each function, and business process model, and compiled key performance indicator from an internal business process angle. In the last step will be discussed learning and growth perspective by designing a risk management plan, and compiled key performance indicators.

\subsection{Marketing Mix}

In the discussion of the balanced scorecard - Customer Perspective, we will use the marketing mix 7P model to outline any strategy designed for this rental business to achieve customers. Marketing mix 7P consists of product, place, promotion, price, people, process, and physical evidence.

\subsection{Company Profile}

PT XYZ was established in 2007 by shareholders who have long been in the motorcycle dealer industry in East Java. The $\mathrm{XYZ}$ motorcycle dealer is domiciled in Tangerang City as its head office and has eleven branch offices scattered throughout the Jabodetabek area. The company sells three product brands: Suzuki, Viar, and Kawasaki, with two types of transactions: cash sales and credit sales. The leasing company partners support credit sales.

Because PT XYZ is an authorized motorcycle dealer, hence its suppliers are brand holder sole agents (Agen Tunggal Pemegang Merek/ATPM). The supplies for motorcycles and spare parts are directly from ATPM. In addition to being a supplier, here ATPM also serves as a regulator and a principle, because as an authorized dealer must fulfill the provisions and standardization of ATPM.

Customers can come from any segments. The sport motorcycle models customers come from the young men segment. Meanwhile, the matic-motorcycle models, its customers can be from workers, teenagers, or mothers that want a small bike and easy to operate. The dirt bike models aimed at customers with adventure and enduro hobbies. Every authorized dealer must have authorized workshop. The workshop customers are the motorcycle owner that need periodic maintenance or repairment for their motorcycles. How to offer the right kind of motorcycle models according to the target segments, it is crucial in this business. Likewise with an excellent aftersales service that can satisfy customers, make added value for motorcycle dealers.

As a motorcycle dealer, PT. XYZ markets three brands of motorcycles: Suzuki, Kawasaki, and Viar, which have significant competitors the market leader: Honda and 
Yamaha. To counter competitors who are market leaders is very difficult, but motorcycle dealers have their loyal customers for these marketed brands and should be able to defend them (see Figure 2).

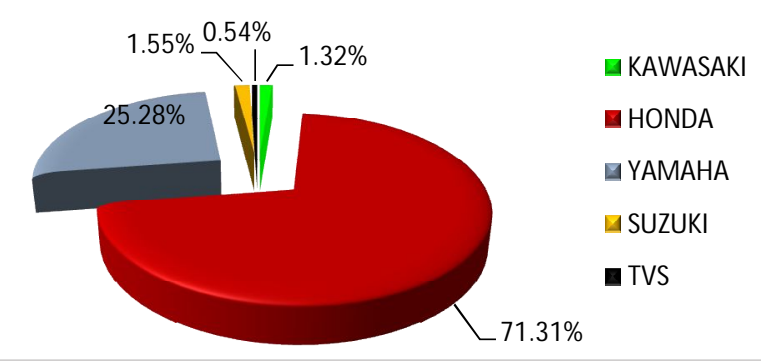

Figure 2: Indonesia Motorcycle Market Share 2017 (Source: AISI)

\section{RESULTS}

\subsection{Initial Preparation}

To be able to evaluate the implementation of a business model, it is measured using the measurement tool balanced scorecard (BSC) with the angle of view: financial perspective, customers perspective, internal business processes perspective, and learning and growth perspective. This evaluation plan aims to obtain a picture of the performance that has been acquired by the company for the implementation of new business processes. Here is the initial preparation to be done to realize this motorcycle rental business:

\subsubsection{Legality Registration}

Following Indonesian Law, this is a list of legalities or licensing of the limited company (Perseroan Terbatas/PT) that needs to be settled sequentially are:

- Deed of Establishment (Akte Pendirian).

- Ministry decree (Pengesahan Menkumham).

- Business Address (Surat Keterangan Domisili Usahal (SKDU).

- Corporate Tax statement (Surat Keterangan Terdaftar and Nomor Pokok Wajib Pajak) (SKT-NPWP).

- Taxation Statement (Surat Pengukuhan Pengusaha Kena Pajak) (SP-PKP).

- Business ID (Nomor Induk Berusaha) (NIB).

- Business License (Surat Izin Usaha Perdagangan) (SIUP).

- Business Location (Tanda Daftar Perusahaan) (TDP) or (Izin Lokasi Usaha).

- Insurance participation license (Sertifikat Kepesertaan BPJS Kesehatan).

\subsubsection{Employee Recruitment}

The next process of the initial preparation of this business is employee recruitment. Because this company will start from zero, not all job positions must be filled from scratch, can be trapped with other appropriate jobs. However, with increasing company turnover and transactions, the addition of employees will be done. Here are the number of employees needed at the beginning and the double jobs map (see Table 1 below).

Table 1: Employee Requirement

\begin{tabular}{|l|l|l|}
\hline NO & \multicolumn{1}{|c|}{ DIVISION } & \multicolumn{1}{c|}{ JOB NAME } \\
\hline 1 & - & CEO (Chief Executive Officer)/Director \\
\hline 2 & - & Team Internal Audit \\
\hline 3 & Marketing & CMO (Chief Marketing Officer) \\
\hline 4 & Operation & COO (Chief Operating Officer) \\
\hline 5 & Financial & CFO (Chief Financial Officer) \\
\hline 6 & Marketing & Promotion \\
\hline 7 & Marketing & Sales Coordinator \\
\hline 8 & Marketing & Sales Administration \\
\hline 9 & Marketing & Sales Counter \\
\hline 10 & Operation & Surveyor \\
\hline 11 & Operation & Delivery \\
\hline 12 & Operation & Customer Care \\
\hline 13 & Operation & Maintenance \\
\hline 14 & Operation & Sparepart \\
\hline 15 & Operation & Mechanic \\
\hline 16 & Financial & Cashier \\
\hline 17 & Financial & Finance \\
\hline 18 & Financial & Accounting-Tax \\
\hline 19 & Financial & IT Support \\
\hline
\end{tabular}

\subsubsection{Applications Creation}

The applications will be created in collaboration with the software house (IT vendor) company. Application specified can be made until the implementation is at most six months. This stage can be done concurrently with the preparation of permits until the recruitment process, for time efficiency. Before the application is ready, for the first six months of the company it operates can use a manual recording of assisted Microsoft Excel.

\subsubsection{Target Market And Product Specifications}

Products marketed are motorcycle rental services. Target market chosen is small micro enterprises (SME), who need a vehicle to support his business, with a low price, easy to use, and can meet to their needs. There are many models of motor vehicles, which in this study was chosen is the three-wheeled vehicle with consideration:

1. Can be used to support transportation business needs.

2. Has a power-load higher than two-wheeled vehicles, although smaller than the car.

3. Easier usage compared to cars. 
4. Can pass a small road terrain, which is not possible for four-wheeled vehicles.

5. The usage of gasoline (Bahan Bahan Minyak/BBM) is relatively more efficient than a car.

The models and specification of motorcycles suitable for this business are (see Table 2):

Table 2: Motorcycle Specifications.

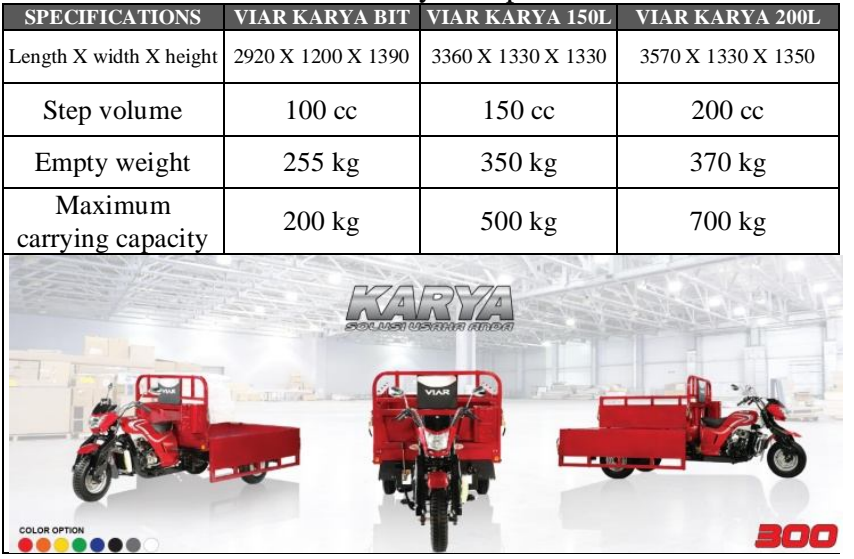

The initial need for motorcycle rental to start this business is 25 units with the composition per models as follows: Viar Karya Bit 5 units, Viar Karya 150L 10 units, and Viar Karya 200L 10 units.

\subsection{BSC - Financial Perspective}

Based on the financial point of view, this motorcycle rental business model will be designed by conducting a financial plan, then projected into three scenarios in the financial projection. With the financial ratio and the feasibility study, we will understand whether this design can be executed or not.

\subsubsection{Financial Plan}

\subsubsection{Capital Funding}

Initial deposit capital is $\mathrm{Rp} 1,500,000,000$ (one billion five hundred thousand rupiahs), and the entire set of shares is 1,000 sheets with the initial value per sheet is $\mathrm{Rp} 1,500,000$ (one million five hundred thousand rupiahs) with the share composition (shown in Table 3):

Table 3: Positions and Responsibilities.

\begin{tabular}{|c|c|c|c|c|}
\hline NO & $\begin{array}{c}\text { SHAREHOLDER } \\
\text { NAME }\end{array}$ & $\begin{array}{c}\text { STOCK } \\
\text { SHEET }\end{array}$ & SHARE VALUE & $\begin{array}{c}\text { PERCENTAGE OF } \\
\text { OWNERSHIP }\end{array}$ \\
\hline 1 & PT.XYZ & 550 & Rp. $825,000,000$ & $55 \%$ \\
\hline 2 & Mr/Ms A & 200 & Rp. $300,000,000$ & $20 \%$ \\
\hline 3 & Mr/Ms B & 100 & Rp. $150,000,000$ & $10 \%$ \\
\hline 4 & Mr/Ms. C & 50 & Rp. $75,000,000$ & $5 \%$ \\
\hline 5 & Mr/Ms. D & 50 & Rp. $75,000,000$ & $5 \%$ \\
\hline 6 & Mr/Ms. E & 50 & Rp. $75,000,000$ & $5 \%$ \\
\hline & & 1.000 & Rp. $1,500,000,000$ & $100 \%$ \\
\hline
\end{tabular}

Worth of total shares Rp1,500,000,000 must be paid in cash to the company's bank account, as the initial capital funding of the company.

\subsubsection{Revenues Target}

At the beginning of the investment is determined by 25 (twenty-five) units of motorcycle rental with model variants are 5 (five) units of Viar Karya Bit model, 10 (Ten) units of Viar Karya 150L model, and 10 (ten) units of Viar Karya 200L model. Revenues target set in 3 (three) scenarios, namely: optimistic, moderate, and pessimistic. In the optimistic scenario, the target occupancy is $95 \%$, moderate $90 \%$, and pessimistic $85 \%$. The target revenue depends on the target occupancy, which indicates how many percents of the average motorcycle unit is rented. Suppose one units motorcycles can operate in a month maximum of 30 (thirty) days, then for the scenario is optimistic between 28-29 days, so 1-2 days of the units are not used. For moderate scenario is 27 days, and the pessimistic scenario is only 25-26 days. Assumed rental prices rose 5\% per year, and the addition of rental motorcycles doubled per year. The formula of the rental price, determined from the price of the motorcycle including the vehicle license costs (Bea Balik Nama/BBN), flat rate per month, replacement units ratio, insurance rates, and maintenance costs (see Table 4).

Table 4: Rent Pricelist

\begin{tabular}{|l|c|c|c|r|}
\hline \multirow{2}{*}{ Type } & Monthly Price & Weekly Price & Daily Price & Average Revenue \\
\cline { 2 - 4 } & $45 \%$ & $50 \%$ & $5 \%$ & Per Unit Per Month \\
\hline Karya Bit & $2,436,000$ & $1,023,120$ & 255,780 & $3,462,165$ \\
\hline Karya 150L & $2,529,000$ & $1,062,180$ & 265,545 & $3,594,341$ \\
\hline Karya 200L & $2,612,000$ & $1,097,040$ & 274,260 & $3,712,305$ \\
\hline \multicolumn{4}{|r|}{} & $3,589,604$ \\
\hline
\end{tabular}

There are 3 (three) rental options customer can choose: daily, weekly, and monthly. On monthly rent, maximum of each motorcycle can be rented 1 (ones) transaction per month. On weekly rent a maximum of 4 (four) times per month, and at a maximum daily rent of 25 (twenty-five) times per month. The transaction is a lease term/contract. Suppose a customer rented a motorcycle on a weekly payment scheme for 2 (two) weeks, considered 2 (two) transactions. Assumed composition of the revenues value of the average rental option per year is $45 \%$ monthly rental, $50 \%$ weekly rent, and 5\% daily rent. It is shown in Table 5.

Table 5: Revenues Target

\begin{tabular}{|c|c|c|c|c|c|c|}
\hline \multirow{2}{*}{} & $\begin{array}{c}\text { TARGET } \\
\text { OCCUPANCY }\end{array}$ & YEAR 1 & YEAR 2 & YEAR 3 & YEAR 4 & YEAR 5 \\
\cline { 2 - 7 } & QTY & $\mathbf{2 5}$ Units & $\mathbf{5 0}$ Units & 100 Units & 200 Units & 400 Units \\
\hline OPTIM ISTIC & $95.0 \%$ & $1,030,301,078$ & $2,163,632,263$ & $4,543,627,752$ & $9,541,618,279$ & $20,037,398,385$ \\
\hline MODERATE & $90.0 \%$ & $976,074,705$ & $2,049,756,881$ & $4,304,489,449$ & $9,039,427,843$ & $18,982,798,470$ \\
\hline PESSIM ISTIC & $85.0 \%$ & $921,848,333$ & $1,935,881,498$ & $4,065,351,146$ & $8,537,237,407$ & $17,928,198,555$ \\
\hline
\end{tabular}

\subsubsection{Operating Expenses}

Operational expenses can be grouped into 8 (eight) group expenses: marketing expenses, maintenance expenses, salary expenses, amortization expenses, fixed assets depreciation expenses, utilities-household expenses, delivery expenses, and information technology (IT) Expenses. Among the eight groups of expenses, the variable cost is delivery expenses, while the others are fixed costs. Delivery cost depends on the 
number of transactions. Some assumptions are used in the calculation of the projected expenses of 5 (five) years. The price increase is assumed to be $3.32 \%$ per year, referring to the inflation rate of July 2019 according to data obtained from the official site of Bank Indonesia.

\subsubsection{Marketing Expenses}

Besides the company profile and website, there are advertising and promotional expenses per month incurred. Advertisements made through social media today being viewed more effectively. Since this business is an added business of an existing business, the promotion to introduce the new business does not need to be done at a high cost (see Table 6).

Table 6: Marketing Expenses Plan

\begin{tabular}{|c|l|c|c|c|c|c|}
\hline NO & PROM OTION ACTIVITIIES & YEAR 1 & YEAR 2 & YEAR 3 & YEAR 4 & YEAR 5 \\
\hline 1 & $\begin{array}{l}\text { Promotion with } \\
\text { Instragram }\end{array}$ & $1,800,000$ & $1,859,760$ & $1,921,504$ & $1,985,298$ & $2,051,210$ \\
\hline 2 & $\begin{array}{l}\text { Promotion with } \\
\text { Telkomsel-MyAds }\end{array}$ & $4,440,000$ & $4,587,408$ & $4,739,710$ & $4,897,068$ & $5,059,651$ \\
\hline 3 & Promotion Banners & $1,440,000$ & $1,487,808$ & $1,537,203$ & $1,588,238$ & $1,640,968$ \\
\hline 4 & Promostion Flags & $2,520,000$ & $2,603,664$ & $2,690,106$ & $2,779,417$ & $2,871,694$ \\
\hline 5 & Brochures & $1,320,000$ & $1,363,824$ & $1,409,103$ & $1,455,885$ & $1,504,221$ \\
\hline \multicolumn{2}{|c|}{ TOTAL } & $\mathbf{1 1 , 5 2 0 , 0 0 0}$ & $\mathbf{1 1 , 9 0 2 , 4 6 4}$ & $\mathbf{1 2 , 2 9 7 , 6 2 6}$ & $\mathbf{1 2 , 7 0 5 , 9 0 7}$ & $\mathbf{1 3 , 1 2 7 , 7 4 3}$ \\
\hline
\end{tabular}

\subsubsection{Maintenance Expenses}

Motorcycle maintenance expenses consist of the motorcycle service charges, the cost of purchasing spare parts, and the cost of buying engine-oil. The first year up to the third year used a real estimate according to the age of spare parts and oils replacement period that usually occurs, based on the experience of the engine motorcycle Viar. For the fourth year will use a reference cost of repair second year plus by taking into price increased for 2 (two) years. For the fifth year will use a reference cost of repair third-year plus by taking into account the rate of increase in the price of 2 (two) years. The first table shows a table of repair costs if the motor is in service at an authorized Viar workshop with a price spare part and oils according to the highest retail price (Harga Eceran Tertinggi/HET) determined by the brand holders sole agent (Agen Tunggal Pemegang Merek/ATPM), without a discount. While the second table is the cost of repair motors performed by the mechanic assuming a margin of $20 \%$, with the consequences there, will be the management of spare parts and oils supplies. Because the item is quite a lot of spare part, and the rotation varies, it is decided a managed spare parts of two months ( 60 days of inventory). It is shown in Table 7.

Table 7: Maintenance Expenses Plan

\begin{tabular}{|c|l|c|c|c|c|c|}
\hline NO & \multicolumn{1}{|c|}{ MODELS } & YEAR 1 & YEAR 2 & YEAR 3 & YEAR 4 & YEAR 5 \\
\hline 1 & Viar Karya Bit & $20,368,300$ & $40,435,216$ & $84,812,240$ & $172,658,735$ & $339,217,996$ \\
\hline 2 & Viar Karya 150L & $26,850,664$ & $95,877,392$ & $142,472,896$ & $409,397,323$ & $638,735,306$ \\
\hline 3 & Viar Karya 200L & $26,850,664$ & $95,877,392$ & $142,472,896$ & $409,397,323$ & $638,735,306$ \\
\hline \multirow{2}{*}{4} & $\begin{array}{l}\text { Vehicle License } \\
\text { Renew }\end{array}$ & - & $12,915,000$ & $26,687,556$ & $55,147,166$ & $113,956,103$ \\
\hline \multicolumn{2}{|c|}{ TOTAL } & $\mathbf{7 4 , 0 6 9 , 6 2 8}$ & $\mathbf{2 4 5 , 1 0 5 , 0 0 0}$ & $\mathbf{3 9 6 , 4 4 5 , 5 8 8}$ & $\mathbf{1 , 0 4 6 , 6 0 0 , 5 4 6}$ & $\mathbf{1 , 7 3 0 , 6 4 4 , 7 1 3}$ \\
\hline \multicolumn{2}{|c|}{ Spare Parts Inventory } & $12,344,938$ & $40,850,833$ & $66,074,265$ & $174,433,424$ & $288,440,785$ \\
\hline Purchasing Spare Parts & $86,414,566$ & $273,610,895$ & $421,669,019$ & $1,154,959,706$ & $1,844,652,074$ \\
\hline
\end{tabular}

\subsubsection{Salary Expenses}

Salary Expenses per year is calculated based on the number of wages each employee needs by this business multiplied by 13 (thirteen) months. It has taken into account the Hari Raya allowance (THR) of a monthly wage issued annually. Employee income tax, PPh article 21, will be cut out of wages, so wages in this calculation already include PPh 21. The wage is inclusive of basic salary, allowances, meals, and transport. The wage has taken into account the government provisions of the provincial minimum wage (Upah Minimum Provinsi/UMP). The UMP of Jakarta City in 2019 is Rp3,940,973. If the job position without a direct subordinate is determined, the minimum wage is UMP, then the immediate supervisor can be determined at least $10 \%$ higher and applies the same to the above level.

Assuming the number of branches increases 1 (one) every year, where there are several job positions that can make concurrently the same work for 2 (two) branches, for the function of surveyor and delivery functions. Some functions can be trapped by other functions (double jobs), usually their direct supervisor, or related functions, which will be adjusted to the job load and transaction amount.

This motorcycle Rental business is designed with the start of recruiting 12 (twelve) employees, and each year is increasing according to the needs and number of transactions targeted. By the end of the fifth year, the company was designed to have 40 (forty) employees. It is shown in Table 8 below.

Table 8: Salary Expenses Plan

\begin{tabular}{|c|c|c|c|c|c|c|}
\hline NO & JOB NAME & YEAR 1 & YEAR 2 & YEAR 3 & YEAR 4 & YEAR 5 \\
\hline & 12 persons & 19 persons & 27 persons & 33 persons & 40 persons \\
\hline 1 & $\begin{array}{c}\text { CEO (Chief Executive } \\
\text { Officer) }\end{array}$ & $70,200,000$ & $72,530,640$ & $74,938,657$ & $77,426,621$ & $79,997,184$ \\
\hline 2 & Team Internal Audit & - & $53,726,400$ & $55,510,116$ & $57,353,052$ & $59,257,174$ \\
\hline 3 & $\begin{array}{c}\text { CMO (Chief Marketing } \\
\text { Officer) }\end{array}$ & $63,700,000$ & $65,814,840$ & $67,999,893$ & $70,257,489$ & $72,590,038$ \\
\hline 4 & $\begin{array}{c}\text { COO (Chief Operating } \\
\text { Officer) }\end{array}$ & $63,700,000$ & $65,814,840$ & $67,999,893$ & $70,257,489$ & $72,590,038$ \\
\hline 5 & $\begin{array}{c}\text { CFO (Chief Financial } \\
\text { Officer) }\end{array}$ & $63,700,000$ & $65,814,840$ & $67,999,893$ & $70,257,489$ & $72,590,038$ \\
\hline 6 & Promotion & - & - & - & $57,353,052$ & $59,257,174$ \\
\hline 7 & Customer Care & - & - & $55,510,116$ & $57,353,052$ & $59,257,174$ \\
\hline 8 & Maintenance Supervisor & $57,200,000$ & $59,099,040$ & $61,061,128$ & $63,088,358$ & $65,182,891$ \\
\hline 9 & $\begin{array}{c}\text { Spare Parts Inventory } \\
\text { Control }\end{array}$ & - & $53,726,400$ & $55,510,116$ & $57,353,052$ & $59,257,174$ \\
\hline 10 & Finance Supervisor & - & - & $55,510,116$ & $57,353,052$ & $59,257,174$ \\
\hline 11 & Accounting-Tax & $52,000,000$ & $53,726,400$ & $55,510,116$ & $57,353,052$ & $59,257,174$ \\
\hline 12 & IT Support & $52,000,000$ & $53,726,400$ & $55,510,116$ & $57,353,052$ & $59,257,174$ \\
\hline 13 & Sales Coordinator & $57,200,000$ & $118,198,080$ & $183,183,384$ & $252,353,430$ & $325,914,455$ \\
\hline 14 & Sales Administration & - & - & - & - & - \\
\hline 15 & Sales Counter & $52,000,000$ & $107,452,800$ & $166,530,349$ & $229,412,209$ & $296,285,868$ \\
\hline 16 & Surveyor & - & $53,726,400$ & $111,020,233$ & $114,706,105$ & $177,771,521$ \\
\hline 17 & Delivery & $52,000,000$ & $53,726,400$ & $111,020,233$ & $172,059,157$ & $296,285,868$ \\
\hline 18 & Mechanic & $52,000,000$ & $107,452,800$ & $16,530,349$ & $229,412,209$ & $296,285,868$ \\
\hline 19 & Cashier & $52,000,000$ & $107,452,800$ & $16,53,30,349$ & $229,412,209$ & $296,285,868$ \\
\hline & TOTAL & $\mathbf{6 8 7 , 7 0 0 , 0 0 0}$ & $\mathbf{1 , 0 9 1 , 9 8 9 , 0 8 0}$ & $\mathbf{1 , 5 7 7 , 8 7 5 , 0 6 1}$ & $\mathbf{1 , 9 8 0 , 1 1 4 , 1 3 2}$ & $\mathbf{2 , 4 6 6 , 5 7 9 , 8 5 5}$ \\
\hline
\end{tabular}

\subsubsection{Amortization Expenses}

Amortization expenses are depreciation of prepaid expenses, with depreciation period adjusted to the benefits. In this case, the amortization expenses are 2 (two) group: pre-operating expenses and office building rental expenses. The period of 
depreciation of pre-operational costs is set at 5 (five) years. The lease period of the building is chosen 2 (two) years with the consideration of investment funds not too large and long enough to evaluate the accuracy of the site selection decision (see Table 9).

Table 9: Amortization Expenses and Prepaid Expenses

\begin{tabular}{|c|c|c|c|c|c|c|}
\hline$\overline{\text { NO }}$ & AMORTIZATION EXPS & $\overline{\text { YEAR } 1}$ & YEAR 2 & $\begin{array}{l}\text { YEAR } 3 \\
\end{array}$ & $\overline{\text { YEAR } 4}$ & YEAR 5 \\
\hline \multicolumn{7}{|c|}{ PRE-OPERATION } \\
\hline 1 & egality Registrations & $1,000,000$ & $1,000,000$ & $1,000,000$ & $1,000,000$ & $1,000,000$ \\
\hline & Company Profile and Website & $3,000,000$ & \begin{tabular}{|l|}
$3,000,000$ \\
\end{tabular} & $3,000,000$ & $3,000,000$ & $3,000,000$ \\
\hline \multicolumn{7}{|c|}{ OFFICE BUILDING RENTS } \\
\hline & & 1 locations & 2 locations & 3 locations & 4 locations & 5 location \\
\hline \multirow[t]{3}{*}{3} & Office Building Rents & $40,000,000$ & $81,328,000$ & $126,728,180$ & $173,635,645$ & $180,865,058$ \\
\hline & TOTAL & $44,000,000$ & $85,328,000$ & $130,728,180$ & $177,635,645$ & \begin{tabular}{|l|}
$184,865,058$ \\
\end{tabular} \\
\hline & PREPAID EXPENSES & $56,000,000$ & $53,328,000$ & $93,400,180$ & $92,235,466$ & $180,865,058$ \\
\hline
\end{tabular}

\subsubsection{Fixed Asset Depreciation Expenses}

The fixed assets needed by this business can be grouped in 5 (five) groups: operating car inventory for delivery transportation, office inventory consisting of office furniture, workshop inventory, information technology inventory, and rental motorcycle inventory. In the dealer business, the sold motorcycles are inventories, while for rental companies, rented motorcycles should be recorded as fixed assets. Car inventory will be depreciated for 8 (eight) years according to the approximate benefits. Office Inventory and workshop inventory will be depreciated for 4 (four) years according to fiscal provisions. IT Inventory consists of laptop devices and software applications, with the estimated time of its benefits, laptops will be depreciated for 4 (four) years, and the software applications will be depreciated for 5 (five) years. In line with the company's development and increase in the number of rental motorcycles, the cost of depreciation of the rental motorcycles inventory will be the highest compared to the depreciation costs of other fixed assets. For the reduction of rental motorcycles set 8 (eight) years according to experience and with consideration of proper routine maintenance. It is shown in Table 10.

Table 10: Fixed Assets Depreciation Expenses Plan

\begin{tabular}{|c|c|c|c|c|c|c|}
\hline NO & FIXED ASSETS & YEAR 1 & YEAR 2 & YEAR 3 & YEAR 4 & YEAR 5 \\
\hline 1 & Operational Cars & $16,200,000$ & $16,200,000$ & $33,493,536$ & $51,361,218$ & $88,282,995$ \\
\hline 2 & Office Inventories & $10,831,725$ & $21,341,436$ & $33,524,838$ & $42,134,414$ & $41,612,300$ \\
\hline 3 & Workshop Inventories & $2,000,000$ & $4,066,400$ & $6,201,405$ & $8,407,291$ & $8,686,413$ \\
\hline 4 & IT Devices Inventories & $70,000,000$ & $76,199,200$ & $82,604,214$ & $87,015,987$ & $81,574,231$ \\
\hline 5 & M Ootorcycles Inventories & $78,047,116$ & $158,685,397$ & $325,316,341$ & $669,642,522$ & $1,381,158,143$ \\
\hline TOTALDEPRECIATION EXPENSES & $\mathbf{1 7 7 , 0 7 8 , 8 4 1}$ & $\mathbf{2 7 6 , 4 9 2 , 4 3 3}$ & $\mathbf{4 8 1 , 1 4 0 , 3 3 3}$ & $\mathbf{8 5 8 , 5 6 1 , 4 3 1}$ & $\mathbf{1 , 6 0 1 , 3 1 4 , 0 8 1}$ \\
\hline \multicolumn{2}{|c|}{ TOTAL BOOK VALUES } & $968,224,990$ & $1,411,940,046$ & $2,485,089,232$ & $4,584,987,646$ & $9,039,760,656$ \\
\hline
\end{tabular}

\subsubsection{Utility And Household Expenses}

Electricity bills and water bills are included in the utility expenses. While the cost of drinking water for employees, the cost of cleaning and the kitchen costs the office is entered to household costs (household expenses). See Table 11 for the details.
Table 11: Utilities and House Hold Expenses Plan

\begin{tabular}{|c|c|c|c|c|c|c|}
\hline NO & EXPENSES & YEAR 1 & YEAR 2 & YEAR 3 & YEAR 4 & YEAR 5 \\
\hline Number of Branch Locations & 1 & 2 & 3 & 4 & 5 \\
\hline Number of Employees & 12 & 19 & 27 & 33 & 40 \\
\hline 1 & Electricity and Water Supply & $1,000,000$ & $2,066,400$ & $3,202,507$ & $4,411,773$ & $5,697,805$ \\
\hline 2 & Drinking Water & 222,000 & 363,170 & 533,217 & 673,347 & 843,275 \\
\hline 3 & Other House Hold Expenses & 250,000 & 516,600 & 800,627 & $1,102,943$ & $1,424,451$ \\
\hline \multicolumn{2}{|c|}{ TOTAL } & $\mathbf{1 , 4 7 2 , 0 0 0}$ & $\mathbf{2 , 9 4 6 , 1 7 0}$ & $\mathbf{4 , 5 3 6 , 3 5 1}$ & $\mathbf{6 , 1 8 8 , 0 6 3}$ & $\mathbf{7 , 9 6 5 , 5 3 2}$ \\
\hline
\end{tabular}

\subsubsection{Information Technology Expenses}

Estimated for software applications development of Rp50,000,000 (fifty million rupiahs) annually begins in the second year. It is also estimated that the rental app license is added when adding branches, amounting to Rp5,000,000 (five million rupiahs) per year based on the initial contract. The cost of cloud rent per year on Azura or AWS is estimated to be Rp2,500,000 (two million five hundred thousand rupiahs) per year, and a domain rental fee of Rp1,000,000 (one million rupiahs) per year. The company's website will be placed on this rented domain. Microsoft Windows 10 operating system license fee is not accounted for in this calculation, assuming every laptop is installed operating system original Windows 10. For Microsoft Office applications using Office 365 with yearly payments and antivirus McAfee 2019 will be extended per year. Other changes in this group are the cost of phone and internet Indihome (usually billed at ones), printer and ink printer costs, payment gateway charges, paper usage cost for printing purposes, and the cost of printing such as receipts, letterhead, invoices, and others. It is shown in Table 12.

Table 12: Information Technology Expenses Plan

\begin{tabular}{|c|c|c|c|c|c|c|}
\hline No & EXPENSES & $\overline{\text { YEAR } 1}$ & $\overline{\text { YEAR 2 }}$ & YEAR 3 & $\overline{\text { YEAR } 4}$ & $\overline{Y E A R 5}$ \\
\hline & Number of Branches & 1 & 2 & 3 & 4 & 5 \\
\hline & Number of Laptop/Notebooks & 10 & 16 & 22 & 26 & 30 \\
\hline 1 & Applications Development & - & $1,660,000$ & $53,375,112$ & $55,147,166$ & 56,978, \\
\hline 2 & Applications License Per Branches & - & $5,000,000$ & $5,000,000$ & $5,000,000$ & $5,000,000$ \\
\hline 3 & \begin{tabular}{|l|} 
Cloud Space Rent \\
\end{tabular} & 500,000 & $2,583,000$ & $2,668,756$ & $2,757,358$ & $2,848,903$ \\
\hline 4 & Domain Fees & $1,000,000$ & $1,033,200$ & $1,067,502$ & $1,102,943$ & $1,139,561$ \\
\hline 5 & Office 365 Licenses & 000 & 6,064 & $13,973,604$ & $17,062,533$ & $20,341,164$ \\
\hline 6 & Antivirus M cAfee 2019 Licenses & 260,000 & 537,264 & 832,652 & $1,147,061$ & $1,481,429$ \\
\hline 7 & Phone and Internet Indohome & 315,000 & 650,916 & $1,008,790$ & $1,389,709$ & \begin{tabular}{|l|}
$1,794,809$ \\
\end{tabular} \\
\hline 8 & Printer Deskjet and Ink & 539,000 & $1,113,790$ & $1,726,151$ & $2,377,946$ & $3,071,117$ \\
\hline 9 & \begin{tabular}{|l} 
Payment Gateway \\
\end{tabular} & 215,000 & 444,276 & 688,539 & 948,531 & $1,225,028$ \\
\hline & Papers and Printing Materials & 150,000 & 309,960 & 480,376 & 661,766 & 854,671 \\
\hline & TOTAL & $10,929,000$ & $73,168,470$ & $80,821,482$ & \begin{tabular}{|l|}
$87,595,013$ \\
\end{tabular} & $94,734,733$ \\
\hline
\end{tabular}

\subsubsection{Delivery Expenses}

Delivery Expenses or the cost of delivering rental motorcycle from the showroom to the customer's location and vice versa is a variable cost, where the value is not fixed and varies depending on the number of transactions set on the revenues target. The delivering cost consists of gasoline costs (BBM), toll-road costs, parking fees, operational car maintenance costs, and the cost of renewal of car's STNK and KIR every year.

It is assumed several conditions in calculating delivering costs: 
1. Operational cars are only used for the delivery of rental motorcycles. It cannot be used for other purposes

2. Premium gasoline price is $\mathrm{Rp} 7000$ per liter

3. Toll-road and parking fees are estimated at Rp1,000,000,per month per car. Toll and parking costs are difficult to predict, tariffs are subject to government provisions, and delivery tracks can be through different roads.

4. The maintenance cost of the car is estimated at Rp1,000,000 per month

5. The cost of renewal of STNK and KIR is estimated Rp2,000,000 per year, where the first year only KIR costs only.

6. A price increase of $3.32 \%$ per year refers to inflation in July 2019.

Based on a pre-defined revenues target, obtained delivery expenses in three scenarios: optimistic, moderate, and pessimistic as follows: (see Table 13).

Table 13: Delivery Expenses Plan

\begin{tabular}{|c|c|c|c|c|c|c|}
\hline NO & EXPENSES & $\overline{\text { YEAR } 1}$ & $\overline{\text { YEAR } 2}$ & $\begin{array}{l}\text { YEAR } 3 \\
\end{array}$ & $\overline{\text { YEAR } 4}$ & YEAR 5 \\
\hline \multicolumn{2}{|c|}{ Number of Delivery Cars } & 1 & 1 & 2 & 3 & 5 \\
\hline 1 & Gasoline Expense & $2,555,000$ & $2,639,826$ & $2,727,468$ & $2,818,020$ & $2,911,578$ \\
\hline 2 & Toll-road and Parking Fee & $12,000,000$ & $12,398,400$ & $24,796,800$ & $37,195,200$ & $61,992,000$ \\
\hline 3 & Car Maintenance & $12,000,000$ & $12,398,400$ & $24,796,800$ & $37,195,200$ & $61,992,000$ \\
\hline 4 & Car Licenses Renewal Tax & $18,000,000$ & $24,796,800$ & $49,593,600$ & $74,390,400$ & $123,984,000$ \\
\hline & TOTAL & $44,555,000$ & $52,233,426$ & $101,914,668$ & $151,598,820$ & $250,879,578$ \\
\hline & $\begin{array}{l}\text { Optimistic Scenario 95\% } \\
\text { Occupancy }\end{array}$ & $42,327,250$ & $49,621,755$ & $96,818,935$ & $144,018,879$ & $238,335,600$ \\
\hline & $\begin{array}{c}\text { Moderate Scenario } 90 \% \\
\text { Occupancy }\end{array}$ & $40,099,500$ & $47,010,083$ & $91,723,201$ & $136,438,938$ & $225,791,621$ \\
\hline & $\begin{array}{c}\text { Pessimistic Scenario 85\% } \\
\text { Occupancy }\end{array}$ & $37,871,750$ & $44,398,412$ & $86,627,468$ & $128,858,997$ & $213,247,642$ \\
\hline
\end{tabular}

\subsubsection{Non-Operating Expenses}

In this motorcycle rental business, there is a non-operating expense: funding interest charges and other expenses. When the business grows, if the capital does not provide sufficient funds or the cash flow is not enough to support operational activities, the company must borrow from financial institutions such as banks or multi-finance companies, even obtain soft loans from shareholders without interest charges. In this research assumed companies borrowed from the Bank. In addition to the cost of interest, other costs that burden the company on borrowing transactions are the provisions and costs of credit contract process (akad kredit), which includes the notary fee, the installation of the rights to the collaterals, etc.

\subsubsection{Interest Expenses}

According to data obtained from the website of the financial services authority (Otoritas Jasa Keuangan/OJK), the average Suku Bunga Dasar Kredit (SBDK) on May 2019 from 19 (nineteen) private banks and government banks in Indonesia is at $10.94 \%$. To assume interest expense in this research is $10.94 \%+0.5 \%=11.44 \%$ pa. The cost of provision and cost of the contract of credit is entered into the cost of interest, with consideration of all these costs regarding funding. The cost of the credit contract may consist of a notary fee, the installation of fiduciary rights, and others, imposed by the bank at the time of credit contract. Interest Expenses is entered into the variable cost class, which is dependent on different cash flow conditions for optimistic, moderate, and pessimistic scenarios. The design of the loan interest fee is calculated based on the minus cash flow that will happen if it does not get additional funds. This business model can use vehicle owner book (Buku Pemilik Kendaraan Bermotor/BPKB) as collateral, with maximum loan value usually $70 \%$ of the motorcycle market value. See Table 14 for the details.

Table 14: Interest Expenses Plan

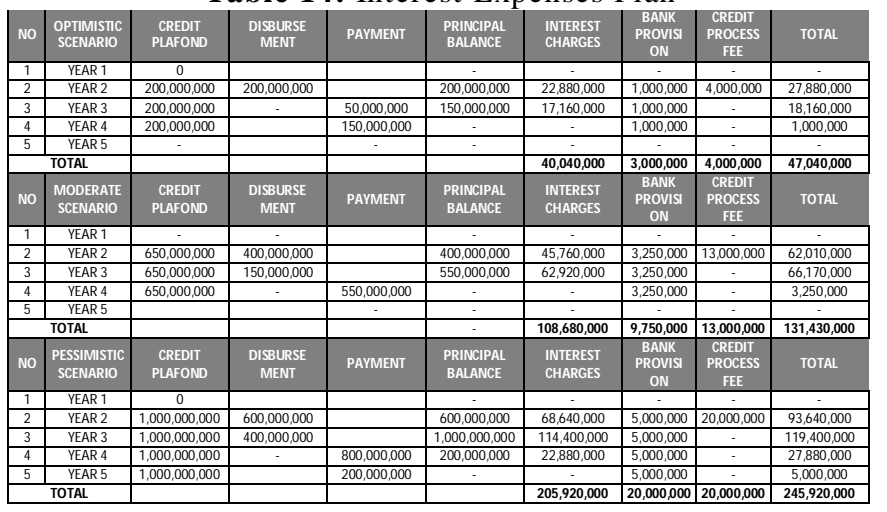

\subsubsection{Others Expenses}

One of the risks in this business is the loss of rental motors when rented or even stored in the office. Similarly, this risk can occur in operating cars. For mitigating risk, this risk of loss can be transferred to the external vehicle insurance company. The expenses that result from mitigating risk of losses are entered into the following miscellaneous charges: (see Table 15).

Table 15: Other Expenses Plan

\begin{tabular}{|c|c|c|c|c|c|c|c|}
\hline NO & EXPENSES & RATES & YEAR 1 & YEAR 2 & YEAR 3 & YEAR 4 & YEAR 5 \\
\hline Number of Cars & & 1 & 2 & 3 & 4 & 5 \\
\hline \multicolumn{2}{|c|}{ Number of Motorcycles } & & 25 & 50 & 100 & 200 & 400 \\
\hline 1 & Car Insurance & $1.68 \%$ & $2,076,480$ & $4,290,838$ & $6,649,941$ & $9,160,959$ & $11,831,378$ \\
\hline 2 & Motorcycle Insurance & $3.82 \%$ & $18,763,151$ & $35,468,789$ & $70,078,309$ & $141,684,414$ & $289,740,258$ \\
\hline \multicolumn{2}{|c|}{ TOTAL } & & $\mathbf{2 0 , 8 3 9 , 6 3 1}$ & $\mathbf{3 9 , 7 5 9 , 6 2 7}$ & $\mathbf{7 6 , 7 2 8 , 2 5 1}$ & $\mathbf{1 5 0 , 8 4 5 , 3 7 2}$ & $\mathbf{3 0 1 , 5 7 1 , 6 3 7}$ \\
\hline
\end{tabular}

\subsubsection{Financial Projection}

Financial projections are designed in three scenarios: optimistic, moderate, and pessimistic, which is distinguished from the level of motor rental occupancy. The selected occupancy rate is $95 \%$ for the optimistic scenario, the occupancy rate is $90 \%$ for the moderate scenario, and the occupancy rate is $85 \%$ for the pessimistic scenario.

The number of revenues and delivery expenses directly affected by the occupancy level. Others are not affected due to their fixed nature. In the cash flow projection, there is a 
fund loan of necessity, which is designed in the fifth year of the loan is all paid off, to facilitate the measurement of business feasibility later. At the design of cash flow set the maximum funds in the bank between Rp100,000,000 (one hundred million rupiahs) to Rp150,000,000 (one hundred and fifty million rupiahs) for operations, the rest will enter deposits with interest 5\% per year, and if less than Rp100,000,000 (one hundred million rupiahs) will be made borrowing funds to enter the range above.

\subsubsection{Optimistic Scenario}

In an optimistic scenario, the company's first year still suffered a loss of 137 million rupiahs, and a positive start in the second year and so on. With a capital of one and half billion rupiahs, the company will have a shortage of funds in the second year, thus requiring a loan of two hundred million rupiahs. In the fifth year, the company's equity will be 15 (fifteen) billion rupiahs assuming there is a dividend distribution in the fifth. The amount of dividend is the number of capital deposits added twice the deposit interest for five years. It is shown in Table 16, 17 and 18.

Table 16: Income Statement - Optimistic Scenario

\begin{tabular}{|c|c|c|c|c|c|c|}
\hline No & REVENUES & YEAR 1 & YEAR 2 & YEAR 3 & YEAR 4 & YEAR 5 \\
\hline 1 & Rental Revenue & $936,637,343$ & $1,966,938,421$ & $4,130,570,683$ & $8,674,198,435$ & $18,215,816,714$ \\
\hline NO & EXPENSES & YEAR 1 & YEAR 2 & $\begin{array}{l}\text { YEAR } 3 \\
\end{array}$ & $\overline{\text { YEAR } 4}$ & $\overline{\text { YEAR } 5}$ \\
\hline 1 & Marketing Expenses & $11,520,000$ & $11,902,464$ & $12,297,626$ & $12,705,907$ & $13,127,743$ \\
\hline 2 & Maintenance Expenses & $74,069,628$ & $245,105,000$ & $396,445,588$ & $1,046,600,546$ & $1,730,644,713$ \\
\hline 3 & Salary Expenses & $687,700,000$ & $1,091,989,080$ & $1,577,875,061$ & $1,980,114,132$ & $2,466,579,855$ \\
\hline 4 & Amortization Expenses & $44,000,000$ & $85,328,000$ & \begin{tabular}{|l|}
$130,728,180$ \\
\end{tabular} & $\begin{array}{l}177,635,645 \\
\end{array}$ & $184,865,058$ \\
\hline 5 & Fixed Assets Depreciation Exp & $177,078,841$ & $276,492,433$ & $481,140,333$ & $858,561,431$ & $1,601,314,081$ \\
\hline$\frac{6}{6}$ & Utilities and Household Exp & $1,472,000$ & $2,946,170$ & $4,536,351$ & $6,188,063$ & $7,965,532$ \\
\hline 7 & Delivery Expenses & $42,327,250$ & $49,621,755$ & $96,818,935$ & $144,018,879$ & $238,335,600$ \\
\hline \multirow[t]{2}{*}{8} & IT Expenses & $10,929,000$ & $73,168,470$ & $80,821,482$ & $87,595,013$ & $94,734,733$ \\
\hline & TOTAL & $1,049,096,719$ & $1,836,553,371$ & $2,780,663,555$ & $4,313,419,618$ & $6,337,567,314$ \\
\hline |No| & $\begin{array}{l}\text { NON OPERATING } \\
\text { INCOM ES/ EXPENSES }\end{array}$ & YEAR 1 & YEAR 2 & YEAR 3 & YEAR 4 & YEAR 5 \\
\hline 1 & Interest Income & 0 & $10,000,000$ & 0 & 0 & $80,000,000$ \\
\hline 2 & Interest Expenses & 0 & $-27,880,000$ & $-18,160,000$ & $-1,000,000$ & 0 \\
\hline \multirow[t]{5}{*}{3} & Others Expenses & $-20,839,631$ & $-39,759,627$ & $-76,728,251$ & $-150,845,372$ & $-301,571,637$ \\
\hline & TOTAL & $-20,839,631$ & $-57,639,627$ & $-94,888,251$ & $-151,845,372$ & $-221,571,637$ \\
\hline & $\overline{\text { PROFIT (LOSS) BEFORETAX }}$ & $-133,299,007$ & $\overline{72,745,423}$ & 1,255,018,878 & $4,208,933,445$ & |11,656,677,763 \\
\hline & INCOME TAX & 0 & 0 & 0 & 0 & 0 \\
\hline & PROFIT (LOSS) AFTER TAX & $-133,299,007$ & $72,745,423$ & $1,255,018,878$ & $4,208,933,445$ & $11,656,677,763$ \\
\hline
\end{tabular}

Table 17: Balance Sheet - Optimistic Scenario

\begin{tabular}{|c|c|c|c|c|c|c|}
\hline N0 & ASSETS & YEAR 1 & EAR 2 & YEAR 3 & & \\
\hline & Cash in Hand & & & & $20,000,000$ & $25,000,000$ \\
\hline 2 & Cash in Bank & $115,447,877$ & $108,809,658$ & $149,730,885$ & $105,436,781$ & $110,267,140$ \\
\hline 3 & Time Deposit & $200,000,000$ & 0 & 0 & $1,600,000,000$ & $5,950,000,000$ \\
\hline 4 & Accounts Receivable & 0 & 0 & 0 & 0 & 0 \\
\hline 5 & $\begin{array}{l}\text { Prepaid Expenses } \\
\end{array}$ & $56,000,000$ & $53,328,000$ & $93,400,180$ & $92,235,466$ & \begin{tabular}{|l}
$180,865,058$ \\
\end{tabular} \\
\hline & Prepaid Tax & & & & & \\
\hline & Inventory & $12,344,938$ & $40,850,833$ & $66,074,265$ & $174,433,424$ & \begin{tabular}{|l|}
$288,440,785$ \\
\end{tabular} \\
\hline \begin{tabular}{|l|}
8 \\
\end{tabular} & Fixed Assets & $1,145,303,832$ & $1,865,511,320$ & $3,419,800,839$ & $6,378,260,685$ & $12,434,347,776$ \\
\hline & Accu. Depreciation Fixed Assets & $-177,078,841$ & $-453,571,274$ & \begin{tabular}{|l|}
$-934,711,607$ \\
\end{tabular} & $-1,793,273,039$ & $-3,394,587,120$ \\
\hline & TOTAL ASSETS & $1,362,017,806$ & $1,624,928,536$ & $2,809,294,561$ & $6,577,093,317$ & $15,594,333,639$ \\
\hline No & LAABILTIES & $\begin{array}{ll}\text { YEAR } 1 \\
\end{array}$ & YEAR 2 & YEAR 3 & 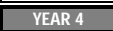 & YEAR 5 \\
\hline & Accounts & 0 & 8 & 0 & ) & 0 \\
\hline \begin{tabular}{|l|}
2 \\
\end{tabular} & Accrued Liabilities & 0 & 0 & 0 & 0 & 0 \\
\hline \begin{tabular}{|l|}
3 \\
\end{tabular} & $\begin{array}{l}\text { Tax Payable } \\
\end{array}$ & 0 & 0 & 0 & 0 & 0 \\
\hline \begin{tabular}{|l|}
4 \\
\end{tabular} & Short-Term Debt & 0 & 0 & 0 & 0 & 0 \\
\hline \multirow[t]{2}{*}{5} & 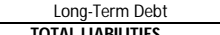 & $\frac{0}{0}$ & $200,000,000$ & \begin{tabular}{|l|l|}
$150,000,000$ \\
15000000
\end{tabular} & 0 & $\frac{0}{0}$ \\
\hline & TOTALLABBIUTIES & 0 & $200,000,000$ & $150,000,000$ & 0 & 0 \\
\hline \multirow{2}{*}{\begin{tabular}{|l|} 
No \\
1 \\
\end{tabular}} & $\begin{array}{c}\text { EQUITY } \\
\text { Capital Stocks }\end{array}$ & $\frac{\text { YEAR 1 }}{1,500,000,000}$ & $\frac{\text { YEAR 2 }}{1,500,000,000}$ & \begin{tabular}{|c|} 
YEAR 3 \\
$1,500,000,000$
\end{tabular} & \begin{tabular}{|c|} 
YEAR 4 \\
$1,500,000,000$
\end{tabular} & $\begin{array}{l}\text { YAAR } 5 \\
1.500,000,000\end{array}$ \\
\hline & $\begin{array}{l}\text { Retained Earnings } \\
\end{array}$ & 0 & $\frac{10}{0}$ & $\frac{100}{0}$ & 0 & 0 \\
\hline \begin{tabular}{|l|}
2 \\
\end{tabular} & $\begin{array}{l}\text { Tahun } 1 \\
\end{array}$ & $-137,982,194$ & \begin{tabular}{|l|l|l|l|l}
$-137,982,194$ \\
\end{tabular} & $-137,982,194$ & \begin{tabular}{|l|}
$-137,982,194$ \\
\end{tabular} & \begin{tabular}{|l|}
$-137,982,194$ \\
\end{tabular} \\
\hline & Tahun 2 & 0 & $62,910,731$ & $62,910,731$ & $62,910,731$ & \begin{tabular}{|l|}
$62,910,731$ \\
\end{tabular} \\
\hline \begin{tabular}{|l|}
4 \\
\end{tabular} & $\begin{array}{l}\text { Tahun } 3 \\
\end{array}$ & 0 & 0 & $1,234,366,025$ & $1,234,366,025$ & \begin{tabular}{|l|}
$1,234,366,025$ \\
\end{tabular} \\
\hline \begin{tabular}{|l|}
5 \\
\end{tabular} & Tahn & 0 & 0 & 0 & $3,917,798,756$ & \begin{tabular}{|l|}
$3,917,798,756$ \\
\end{tabular} \\
\hline \begin{tabular}{|l|l|}
6 \\
\end{tabular} & Tahun 5 & 0 & 0 & 0 & 0 & \begin{tabular}{|l}
$1,272,725,357$ \\
225,25025
\end{tabular} \\
\hline \begin{tabular}{|l|l}
7 \\
\end{tabular} & Dividend & 0 & 0 & 0 & 0 & \begin{tabular}{|l|}
$-2,255,485,035$ \\
\end{tabular} \\
\hline & TOTAL EQUITY & $1,362,017,806$ & $1,424,928,536$ & $2,659,294,561$ & $6,577,093,317$ & $15,594,333,639$ \\
\hline & & & & & & \\
\hline
\end{tabular}

Table 18: Cash Flow - Optimistic Scenario

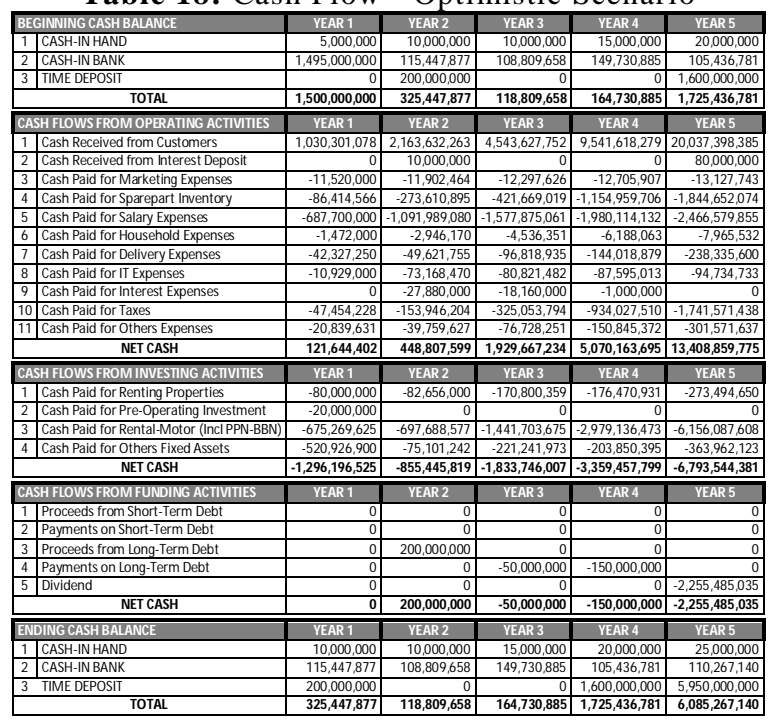

\subsubsection{Moderate Scenario}

In moderate scenarios, the first and second years of the company still suffered a loss of 184 million rupiahs and 74 million rupiahs and a positive starting profit for the third year onward. With the capital of one and half billion rupiahs, the company will have a shortage of funds in the second year and third year, so it requires a loan of 550 million rupiahs to cover the shortfall of cash flow during the 2 (two) years. In the fifth year, the company's equity will be 13 (thirteen) billion rupiah assuming there is a dividend distribution in the fifth year. The significant dividends are designed for the number of capital deposits added twice the deposit interest for five years. The Table 19, 20, and 21 show moderate scenario of financial analysis.

Table 19: Income Statement - Moderate Scenario

\begin{tabular}{|c|c|c|c|c|c|c|}
\hline No & REVENUES & $\overline{\text { YEAR } 1}$ & $\overline{\text { YEAR } 2}$ & YEAR 3 & YEAR 4 & YEAR 5 \\
\hline$\frac{N}{1}$ & \begin{tabular}{l|l}
1 & Rental Revenue \\
\end{tabular} & $887,340,641$ & $1,863,415,346$ & $3,913,172,226$ & $8,217,661,675$ & $17,257,089,518$ \\
\hline NO & EXPENSES & YEAR 1 & YEAR 2 & YEAR 3 & YEAR 4 & YEAR 5 \\
\hline \begin{tabular}{|l|l}
1 & \\
\end{tabular} & Marketing Expenses & $11,520,000$ & $11,902,464$ & $12,297,626$ & $12,705,907$ & $13,127,743$ \\
\hline \begin{tabular}{|l}
2 \\
\end{tabular} & Maintenance Expenses & $74,069,628$ & $245,105,000$ & $396,445,588$ & $1,046,600,546$ & $1,730,644,713$ \\
\hline \begin{tabular}{|c|}
3 \\
\end{tabular} & Salary Expenses & $687,700,000$ & $1,091,989,080$ & $1,577,875,061$ & $1,980,114,132$ & $2,466,579,855$ \\
\hline \begin{tabular}{|l}
4 \\
\end{tabular} & Amortization Expenses & $44,000,000$ & $85,328,000$ & $130,728,180$ & $177,635,645$ & $184,865,058$ \\
\hline 5 & Fixed Assets Depreciation Exp & $177,078,841$ & $276,492,433$ & $481,140,333$ & $858,561,431$ & \begin{tabular}{|l|}
$1,601,314,081$ \\
\end{tabular} \\
\hline \begin{tabular}{|l|l|l}
6 \\
\end{tabular} & Utilities and Household Exp & $1,472,000$ & $2,946,170$ & $4,536,351$ & $6,188,063$ & $7,965,532$ \\
\hline \begin{tabular}{|l|l}
7 \\
\end{tabular} & Delivery Expenses & $40,099,500$ & $47,010,083$ & $91,723,201$ & $136,438,938$ & $225,791,621$ \\
\hline \begin{tabular}{|l|}
8 \\
\end{tabular} & IT Expenses & $10,929,000$ & $73,168,470$ & $80,821,482$ & $87,595,013$ & $94,734,733$ \\
\hline & TOTAL & $1,046,868,969$ & $1,833,941,700$ & $2,775,567,821$ & $4,305,839,677$ & $6,325,023,335$ \\
\hline No & $\begin{array}{l}\text { NON OPERATING } \\
\text { INCOM ES/ EXPENSES }\end{array}$ & YEAR 1 & YEAR 2 & YEAR 3 & YEAR 4 & YEAR \\
\hline 1 & Interest Income & 0 & $7,500,000$ & 0 & 0 & $35,000,000$ \\
\hline \begin{tabular}{|l|}
2 \\
\end{tabular} & Interest Expenses & 0 & $-62,010,000$ & $-66,170,000$ & $-3,250,000$ & 0 \\
\hline & Others Expenses & $-20,839,631$ & $-39,759,627$ & $-76,728,251$ & $-150,845,372$ & $\begin{array}{l}-301,571,637 \\
\end{array}$ \\
\hline & TOTAL & $-20,839,631$ & $-94,269,627$ & $-142,898,251$ & $-154,095,372$ & $-266,571,637$ \\
\hline & 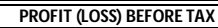 & $\overline{-180,367,960}$ & $\overline{-64,795,981}$ & $9994,706,155$ & $3,757,726,626$ & $10,665,494,547$ \\
\hline & INCOME TAX & 0 & 0 & 0 & 0 & 0 \\
\hline & PROFIT (LOSS) AFTER TAX & $-180,367,960$ & $-64,795,981$ & $994,706,155$ & $3,757,726,626$ & $10,665,494,547$ \\
\hline
\end{tabular}


Table 20: Balanced Sheet - Moderate Scenario

\begin{tabular}{|c|c|c|c|c|c|}
\hline ASSETS & YEAR 1 & YEAR 2 & YEAR 3 & YEAR 4 & $\begin{array}{l}\text { YEAR } 5 \\
\end{array}$ \\
\hline 1 Cash in Hand & $10,000,000$ & $10,000,000$ & $15,000,000$ & $20,000,000$ & \\
\hline \begin{tabular}{|l|l|}
2 & Cash in Bank \\
\end{tabular} & $118,625,409$ & $124,963,401$ & $106,658,897$ & $127,928,001$ & \\
\hline \begin{tabular}{|l|l}
3 & Time Deposit \\
\end{tabular} & $150,000,000$ & & & $700,000,000$ & $4,100,000,000$ \\
\hline 4 Accounts Receivable & & & & & \\
\hline 5 Prepaid Expenses & $56,000,000$ & $53,328,000$ & $93,400,180$ & $92,235,466$ & $180,865,058$ \\
\hline $\begin{array}{lll}6 & \text { Prepaid Tax } \\
\end{array}$ & & & & & \\
\hline \begin{tabular}{|l|l|}
7 & Inventory \\
\end{tabular} & $12,344,938$ & $40,850,833$ & $66,074,265$ & $174,433,424$ & $288,440,785$ \\
\hline \begin{tabular}{|l|l|}
8 & Fixed Assets \\
\end{tabular} & {$[145,303,832$} & $1,865,511,320$ & $3,419,800,839$ & \begin{tabular}{|l}
$6,378,260,685$ \\
\end{tabular} & $12,434,347,776$ \\
\hline 9 Accu. Depreciation Fixed Assets & $-1777,078,841$ & $-453,571,271$ & $-934,711,607$ & $-1,793,273,039$ & $-3,394,587,120$ \\
\hline TOTAL ASSETS & $1,315,195,337$ & $1,641,082,28 \mathrm{C} \longrightarrow \mathrm{C}$ & $2,766,222,573$ & $5,699,584,537$ & $13,738,772,727$ \\
\hline "IABBILTEES & $\begin{array}{l}\text { YEAR } 1 \\
\end{array}$ & $\overline{\text { YEAR } 2}$ & $\begin{array}{l}\text { YEAR } 3 \\
\end{array}$ & $\overline{\text { YEAR } 4}$ & YEAR 5 \\
\hline \begin{tabular}{|l|l|}
1 & Accounts Payable \\
\end{tabular} & 0 & & & & \\
\hline 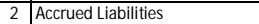 & 0 & & & & \\
\hline 3 Tax Payable & 0 & & & & \\
\hline 4 Short-Term Debt & & & & & \\
\hline \begin{tabular}{|l|l|}
5 & Long-Term Debt \\
\end{tabular} & & $400,000,000$ & $550,000,000$ & & \\
\hline $\begin{array}{l}\text { TOTAL LABIUTIES } \\
\end{array}$ & $\overline{0}$ & $400,000,00 \mathrm{C}$ & $550,000,000$ & & \\
\hline EQUITY & YEAR 1 & YEAR 2 & YEAR 3 & & \\
\hline 1 Capital Stocks & 300,0 & $500,000,000$ & . $500,000,000$ & $1,500,000,000$ & $1,500,000,000$ \\
\hline Retained Earnings & & & & & \\
\hline \begin{tabular}{|l|l|}
2 & Tahun 1 \\
\end{tabular} & $-184,804,663$ & $-184,804,66$ & $-184,804,663$ & $-184,804,663$ & $-184,804,663$ \\
\hline Tahun 2 & & $-74,113,057$ & $-74,113,057$ & $-74,113,057$ & $-74,113,057$ \\
\hline \begin{tabular}{|l|l|}
4 & Tahun 3 \\
\end{tabular} & 0 & & $975,140,294$ & $975,140,294$ & 975,140,294 \\
\hline $\begin{array}{l}\text { Tahun } 4 \\
\end{array}$ & 0 & & & $3,483,361,963$ & $3,483,361,963$ \\
\hline \begin{tabular}{|l|l|}
6 & Tahun 5 \\
\end{tabular} & & & & & $0,294,673,226$ \\
\hline 7 Dividend & $\overline{0}$ & & & & $2,255,485,03$ \\
\hline $\begin{array}{l}\text { TOTAL EQUITY } \\
\end{array}$ & $115,195,337$ & $1,241,082,28 \mathrm{C}, \mathrm{C}, \mathrm{C}$ & 2,216,222,573 & $5,699,584,537$ & $\frac{3,738,772,727}{3,1}$ \\
\hline TAL EQUITY + TOTAL & $1,315,195,337$ & $\overline{1,6}$ & $\overline{2,766,222,5}$ & 5,699,584,537 & $13,738,772,727$ \\
\hline
\end{tabular}

Table 21: Cash Flow - Moderate Scenario

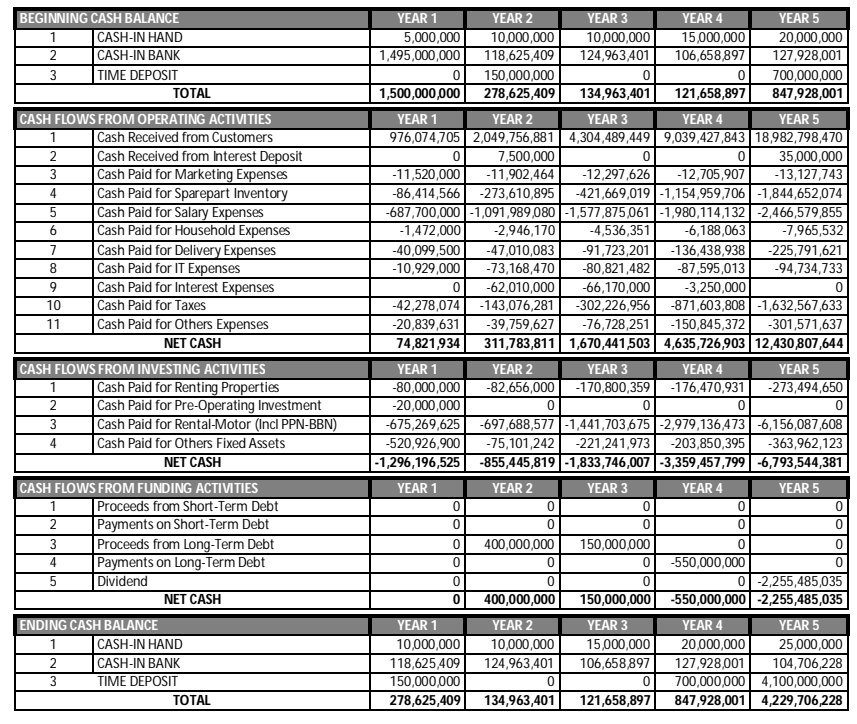

\subsubsection{Pessimistic Scenario}

In pessimistic scenarios, the first and second years of the company still suffered a loss of 231 million rupiahs and 208 million rupiahs and a positive starting profit in the third year onward. With the capital of one and half billion rupiahs, the company will have a shortage of funds in the second year and third year, so it requires a loan of 1.1 billion rupiahs to cover the shortfall of cash flow during the 2 (two) years. In the fifth year, the company's equity will be 11 (eleven) billion rupiahs assuming there is a dividend distribution in the fifth year. Significant dividends are designed for the number of capital deposits added twice the deposit interest for five years. We attach the pessimistic financial scenario as stated in Table 22, 23 and 24.
Table 22: Income Statement - Pessimistic Scenario

\begin{tabular}{|c|c|c|c|c|c|c|}
\hline \multirow{2}{*}{\multicolumn{2}{|c|}{\begin{tabular}{|c|c} 
NO & REVENUES \\
1 & Rental Revenue \\
\end{tabular}}} & $\frac{Y E A R 1}{Y Z A}$ & YEAR 2 & $\begin{array}{ll}\text { YEAR } 3 \\
\text { VAR }\end{array}$ & 24 & $298,362,3$ \\
\hline & & $38,043,9$ & $759,892,2$ & $95,773,7$ & $761,124,916$ & , 298, \\
\hline \multirow{2}{*}{\multicolumn{2}{|c|}{\begin{tabular}{l|l}
1 & Marketing Expenses \\
\end{tabular}}} & TEA & $\overline{\text { YEAR } 2}$ & $\overline{\text { YEAR: }}$ & & \\
\hline & & $11,520,000$ & $11,902,464$ & $12,297,626$ & $12,705,907$ & $13,127,743$ \\
\hline \multicolumn{2}{|c|}{\begin{tabular}{c|l}
1 & Marketing Expenses \\
2 & Maintenance Expense
\end{tabular}} & $74,069,628$ & $245,105,000$ & $396,445,588$ & $1,046,600,546$ & $1,730,644,71$ \\
\hline & & & $\overline{11,091,9}$ & & & \\
\hline & Amortization Expenses & & & & & \\
\hline & Fixed Assets Depreciation Exp & & & & & \\
\hline & Utilities and Household Exp & & & & & \\
\hline & $\begin{array}{l}\text { Utillities and Hous } \\
\text { Delivery Expenses } \\
\end{array}$ & & & & & \\
\hline & \begin{tabular}{|l} 
Delivery Expenses \\
IT Expenses
\end{tabular} & & & & & \\
\hline & $\begin{array}{r}\text { TIT Expenses } \\
\text { TOTAL }\end{array}$ & 44,6 & $\frac{1,831,2}{1,2}$ & ,770, & ,298, & ,312,479,35 \\
\hline \multirow{2}{*}{$\frac{\text { No }}{1}$} & $\begin{array}{l}\text { NON OPERATING } \\
\text { INCOMES/ EXPENSES }\end{array}$ & YEAR 1 & YEAR 2 & YEAR 3 & YEAR 4 & YEAR 5 \\
\hline & Interest Income & & & & & \\
\hline & \multirow[t]{2}{*}{ Interest Expenses } & & & & & $\frac{0,00}{, 00}$ \\
\hline & & & & & & -301 \\
\hline & Others Expenses & & $-128,399,627$ & $-196,128,251$ & -178 & -30 \\
\hline & & & $\begin{array}{ll}-199,837,384 \\
\end{array}$ & $\begin{array}{ll}729,173,431 \\
\end{array}$ & & \\
\hline \multirow{2}{*}{\multicolumn{2}{|c|}{$\begin{array}{c}\text { PROFIT (LOSS) BEFORE TAX } \\
\text { INCOM EAX } \\
\text { PROFIT (LOSS) AFTER TAX }\end{array}$}} & & & & & \\
\hline & & $.227,436$ & $99,837,384$ & 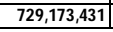 & 284.139808 & \\
\hline
\end{tabular}

Table 23: Balanced Sheet - Pessimistic Scenario

\begin{tabular}{|c|c|c|c|c|c|}
\hline \multicolumn{6}{|l|}{$\begin{array}{l}\text { ASSEIS } \\
\text { Cash in Hand }\end{array}$} \\
\hline $\begin{array}{ll}1 & \text { Cash in Hand } \\
\end{array}$ & & $10,000,000$ & $15,000,000$ & $20,000,000$ & $25,000,000$ \\
\hline 2 Cash in Bank & $121,802,940$ & $143,617,144$ & $110,866,909$ & $\mid 129,022,326$ & $134,109,188$ \\
\hline $\begin{array}{lll}3 & \text { Time Deposit } \\
\end{array}$ & $1100,000,000$ & & & & \begin{tabular}{|l|}
$2,200,000,000$ \\
\end{tabular} \\
\hline \begin{tabular}{l|l}
4 & Accounts Receivable
\end{tabular} & & & & & \\
\hline 5 Prepaid Expenses & $56,000,000$ & $53,328,000$ & $93,400,180$ & $92,235,466$ & $180,865,058$ \\
\hline \begin{tabular}{|l|l|}
6 & Prepaid Tax \\
\end{tabular} & & & & & \\
\hline 77 Inventory & $12,344,938$ & $40,850,833$ & $66,074,265$ & $174,433,424$ & $288,440,785$ \\
\hline \begin{tabular}{l|l}
8 & Fixed Assets
\end{tabular} & \begin{tabular}{|l|}
$1,145,303,832$ \\
\end{tabular} & $865,511,320$ & $3,419,800,839$ & \begin{tabular}{|l|}
$6,378,260,685$ \\
\end{tabular} & $12,434,347,776$ \\
\hline 99 Accu. Depreciation Fixec & $-177,078,841$ & $-453,571,274$ & $-934,711,607$ & $1,793,273,039$ & \begin{tabular}{|l|}
$-3,394,587,120$ \\
\end{tabular} \\
\hline TOTALASSETS & $1,268,372,868$ & & & \begin{tabular}{|l|}
$5,000,678,862$ \\
\end{tabular} & $\begin{array}{ll}11,868,175,688 \\
\end{array}$ \\
\hline LAABILTIES & YEAR 1 & YEAR 2 & YEAR 33 & YEAR 4 & YEAR 5 \\
\hline \begin{tabular}{l|l}
1 & Accounts Payable \\
\end{tabular} & 0 & & & & \\
\hline 2 Accrued Liabilities & 0 & & & & \\
\hline Tax Payable & 0 & & & & \\
\hline \begin{tabular}{l|l}
4 & Short-Term Debt \\
\end{tabular} & 0 & & & & \\
\hline 5 Long-Term Debt & & $600,000,000$ & $000,000,000$ & $200,000,000$ & \\
\hline TOTAL LABIUTIES & 0 & $600,000,000$ & $1,000,000,000$ & $200,000,000$ & \\
\hline EQUITY & $\overline{\text { YEAR } 1}$ & YEAR 2 & YEAR 3 & YEAR 4 & \\
\hline \begin{tabular}{c|c}
1 & Capital Stocks \\
\end{tabular} & $1,500,000,000$ & $500,000,000$ & $1,500,000,000$ & $1,500,000,000$ & $1,500,000,000$ \\
\hline $\begin{array}{ll}\text { Retained Earnings } \\
\end{array}$ & & & & & \\
\hline $\begin{array}{lll}2 & \text { Tahun } 1 \\
\end{array}$ & \begin{tabular}{|l|}
$-231,627,132$ \\
\end{tabular} & $231,627,132$ & 7,132 & $-231,627,132$ & $-231,627,132$ \\
\hline Tahun 2 & ( & $-208,636,846$ & $-208,636,846$ & $-208,636,846$ & $-208,636,846$ \\
\hline Tahun 3 & 0 & & $710,694,562$ & $710,694,562$ & $710,694,562$ \\
\hline Tahun 4 & 0 & 0 & & $3,030,248,277$ & $3,030,248,277$ \\
\hline Tahun 5 & 0 & & & & \begin{tabular}{|l|}
$9,322,981,861$ \\
\end{tabular} \\
\hline Dividend & & & & & \begin{tabular}{|l|l|}
$-2,255,485,035$ \\
\end{tabular} \\
\hline TOTAL EQUITY & \begin{tabular}{|l|}
$1,268,372,868$ \\
\end{tabular} & $1,059,736,023$ & $1,770,430,585$ & $4,800,678,862$ & \\
\hline$\overline{\text { ALEQUITY + TOTALLU }}$ & $8,372,86$ & $1,659,736,023$ & $2,770,430$, & $5,000,678,862$ & $11,868,175,68$ \\
\hline
\end{tabular}

Table 24: Cash Flow - Pessimistic Scenario

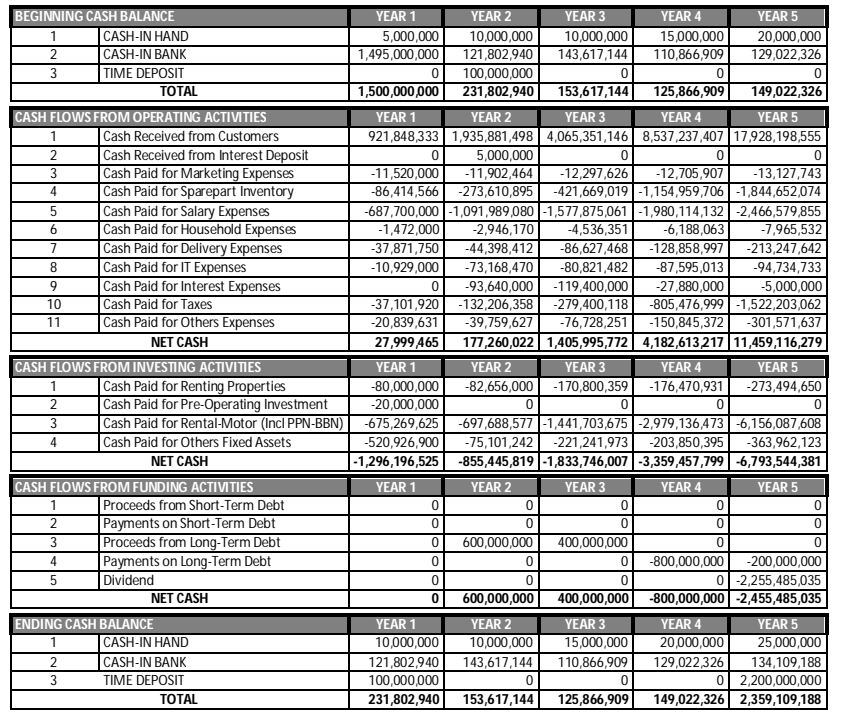




\subsubsection{Financial Ratio}

Seen in Table 25 for all three scenarios, the ROE, ROA, ROI, and Net Profit Margin financial ratios continue to increase over five years. Until in the fifth year, ROE and ROA gained between $72.3 \%-78.6 \%$, which shows the performance of equity or asset running well.

Table 25: Financial Ratios

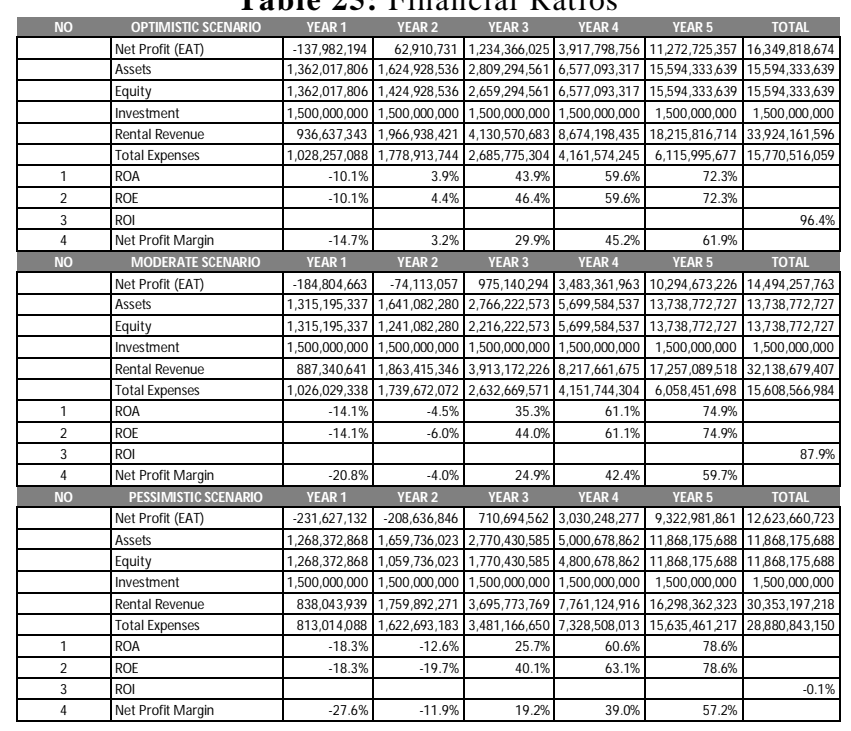

\subsubsection{Feasibility Study}

Feasibility study in an optimistic scenario, moderate scenario, and pessimistic scenario are using NPV, IRR, and payback period. Assuming interest rates are $4.25 \%$ per year, referring to the 1-month deposit rate at Bank Mandiri in August 2019.

In an optimistic scenario, the feasibility was obtained: NPV Rp4,013,476,571 and IRR 51.51\% with Payback Period 2.5 years. In a moderate scenario, the feasibility is obtained: NPV Rp2,454,242,387 and IRR 31.17\%, with Payback Period 2.7 years. In pessimistic scenarios, the feasibility is obtained: NPV Rp889,568,045 and IRR 13.24\%, with a Payback Period of 3 years. Table 26 illustrates these values.

Table 26: Feasibility Study (NPV, IRR and Payback Period)

\begin{tabular}{|r|r|r|r|}
\hline & \multicolumn{1}{|c|}{ NPV } & \multicolumn{1}{|c|}{ IRR } & Payback Period (in Years) \\
\hline Feasible Criteria & NPV $>0$ & IRR $>$ Deposits Rate & reasonable \\
\hline Optimistic Scenario & $4,013,476,571$ & $51.55 \%$ & 2.5 \\
\hline M oderate Scenario & $2,454,242,387$ & $31.17 \%$ & 2.7 \\
\hline Pessimistic Scenario & $889,568,045$ & $13.24 \%$ & 3.0 \\
\hline
\end{tabular}

\subsubsection{Net Present Value (NPV)}

From five years of financial projection, the motorcycle rental business model is in an optimistic scenario, acquired NPV $\mathrm{Rp} 4,013,476,571$, in moderate scenario $\mathrm{Rp} 2,454,242,387$ and in pessimistic scenario of Rp889,568,045. This NPV figure is obtained assuming a deposit interest of $4.25 \%$ refers to the one-month deposit interest in Bank Mandiri valid in August 2019. Net Present Value (NPV) of the three scenarios is positive, and the motorcycle rental business model deserves to run.

\subsubsection{Interest Rate Return (IRR)}

From five years of financial projection, this motorcycle rental business model benefits from IRR $51.51 \%$ for optimistic scenarios, IRR $31.17 \%$ for the moderate scenario, and IRR $13.24 \%$ for pessimistic scenarios. This figure is far above the highest current deposit interest. It can be concluded this business model appeals to investors to run.

\subsubsection{Payback Period}

The payback period shows when the investment returns. The payback period for this motorcycle rental business is $2.5-3$ years. The figure is derived from the financial projections in the optimistic scenario of 2.5 years, in a moderate scenario of 2.7 years, and three years in the pessimistic scenario. Three years is not a long time for an investment. Hopefully, by looking at this figure, investors are interested in investing their investments in this business.

\subsubsection{Key Performance Indicators}

Here are four financial objectives that you want to achieve with this motorbike rental business: (see Table 27 below).

Table 27: Financial Perspective KPI

\begin{tabular}{|l|l|l|l|}
\hline NO & \multicolumn{1}{|c|}{$\begin{array}{c}\text { STRATEGIC } \\
\text { OBJECTIVES }\end{array}$} & \multicolumn{1}{|c|}{ MEASURES } & \multicolumn{1}{c|}{ TARGETS } \\
\hline 1 & Increase Revenues & $\begin{array}{l}\bullet \text { Number of transactions } \\
\text { Transactions Value (in } \\
\text { Rupiahs) }\end{array}$ & $\begin{array}{l}\text { - Number of transactions growth } \\
100 \% \text { per year } \\
\text { Transactions value growth } 100 \% \\
\text { per year }\end{array}$ \\
\hline 2 & $\begin{array}{l}\text { Decrease Operating } \\
\text { Expenses }\end{array}$ & $\begin{array}{l}\text { Reduced expenses } \\
\text { percentage over revenues }\end{array}$ & $1 \%$ reduction minimum per year \\
\hline 3 & Increase Profitability & Increased profit margins & $\begin{array}{l}\text { Increased profit margin compared to } \\
\text { the previous year }\end{array}$ \\
\hline 4 & $\begin{array}{l}\text { Increase Financial } \\
\text { Performance Indicators }\end{array}$ & ROI dan ROE & $\begin{array}{l}\text { Above } 1.5 \text { times the average bank } \\
\text { deposit interest rate }\end{array}$ \\
\hline 5 & Annual Dividend & $\begin{array}{l}\text { Dividend payment to } \\
\text { stockholders }\end{array}$ & $\begin{array}{l}\text { In the } 5^{\text {th }} \text { year, pay dividend worth } \\
\text { the initial capital deposit plus twice } \\
\text { bank deposit interest for five years } \\
\text { After } 5^{\text {th }} \text { year, pay annual dividend } \\
\text { worth twice bank deposit interest }\end{array}$ \\
\hline 6 & Expenses monitoring & Annual budget evaluation & $\begin{array}{l}\text { Realization vs. budget deviations lower } \\
\text { than } 5 \%\end{array}$ \\
\hline
\end{tabular}

\subsection{BSC - Customers Perspective}

\subsubsection{Marketing Mix}

The target market for this motorcycle rental business model is the small and micro enterprises (SME) entrepreneurs. Here is the $7 \mathrm{P}$ marketing mix to reach the motorcycle rental business's target market: 


\subsubsection{Product}

The most significant and most important thing in starting a new business is determining the products to be offered. Products should be able to answer the expectations of targeted customer segments. In this business model, the products offered in the form of services, motorcycle rental services. The choice of motorcycle type offered is the threewheeled motorcycles, to fulfill the needs of the transportation vehicle for the SME entrepreneurs.

These motorcycles are smaller than cars so that they can pass through small streets and alleys. Three-wheeled motorcycles offered has a considerable carrying capacity, much higher than the carrying power of the two-wheeled motor.

This vehicle is easy to operate, easy to drive because it is only required rider license SIM-C and the ability to drive a two-wheeled motorcycle. Also easy to obtain, by making rental payments and providing requirements ID-Cards and papers, the motorcycle can be directly used. Unlike the purchase of a new motorcycle, which will need time to process for the approval of the motor credit and need time for the management of vehicle licenses (STNK and BPKB). With the purchase of a motorcycle on credit, at least one month up to the motor can be used.

For the SME entrepreneurs who are pioneering their business, this motorcycle rental is a solution to obtain a transport motorcycle with a relatively small investment and do not have difficulties like buying with credit, in meeting the credit requirements from the bank or multi-finance companies.

Rental motorcycles have many advantages because they are equipped with vehicle license, the selection of flexible rental period (daily, weekly, or monthly), and includes maintenance and repairment costs during the rental period. Lessee only need to withdraw funds for rent and the cost of fuel (BBM) only.

The three-wheeled motor offered is the Viar branded motor which has become the leader of the three-wheeled class in Indonesia. Viar excels because of the large number of sales and the breadth of the dealer area and workshop network in Indonesia. Using Viar brand, motor quality is more secure than the other three-wheeled motorcycle brands.

\subsubsection{Price}

By comparing the rental price with the monthly installments for the same type of motorcycles, data is obtained in the table below. Down payment and installments are derived from ADIRA's pricelist leasing in force in August 2019. The Table 28 illustrates the comparison of the values.
Table 28: Rental and Installment Comparison

\begin{tabular}{|c|c|c|c|c|c|c|}
\hline No & MODELS & $\begin{array}{c}\text { DOWN } \\
\text { PAYMENT }\end{array}$ & $\begin{array}{c}\text { INSTALLMINNT } \\
11 \text { MONTHS }\end{array}$ & $\begin{array}{c}\text { INSTALLMENT } \\
\text { 23 MONTHS }\end{array}$ & $\begin{array}{c}\text { INSTALLMENT } \\
\text { 35 MONTHS }\end{array}$ & $\begin{array}{c}\text { RENT } \\
\text { PRICE }\end{array}$ \\
\hline 1 & $\begin{array}{c}\text { VIAR KARYA } \\
\text { BIT }\end{array}$ & $3,500,000$ & $2,321,000$ & $1,322,000$ & $1,030,000$ & $2,424,000$ \\
\hline 2 & $\begin{array}{c}\text { VIAR KARYA } \\
150 L\end{array}$ & $3,500,000$ & $2,778,000$ & $1,581,000$ & $1,232,000$ & $2,516,000$ \\
\hline 3 & $\begin{array}{c}\text { VIAR KARYA } \\
\text { 200L }\end{array}$ & $3,500,000$ & $3,038,000$ & $1,729,000$ & $1,347,000$ & $2,600,000$ \\
\hline
\end{tabular}

The monthly rental price is seen approximately equal to monthly installments in the down payment Rp3,500,000 and the term of payment 11 (eleven) months. The rental price includes a regular maintenance fee consisting of service, spare parts, and oil, and also includes a vehicle license STNK renewal fee annually. Free rental periods, can be daily, weekly, or monthly. With the rental price and facilities acquired, it should be acceptable to the customers.

With the choice of daily, weekly, or monthly rental prices, this business should be able to reach all the economic layers of the community, especially the SME entrepreneurs. With the absence of competitors for the third-wheel motor vehicle rental, the rental price is not able to be assessed too high or too low on the market.

\subsubsection{People}

People here are the founders/owners and employees. The founders and the shareholders are occupied the position of top management in the organization, is expected to provide proper direction for all employees to be able to provide the best performance, especially in terms of customer services. Because to cultivate excellent services for an organization, need leadership, environment, and supporting facilities, as well as appropriate standard operating procedure (SOP). The minimum SOP required by the company to give excellent services is:

1. SOP about customers prospecting includes the appearance of employees who are directly related to the customer, how to communicate well, proper product recognition, and adequate training.

2. SOP about customer complaints handling, including customer complaints due to application use, complaints about motorcycle conditions, and complaints about employee service.

3. SOP about compensation for customers includes how the compensation decision is decided and how compensation is made.

4. SOP about customer satisfaction assessment

\subsubsection{Place}

Where customers can make a transaction is directly in the showroom or office, through the phone and WhatsApp media, or through a mobile application via the Internet. The three places such transactions have the following weaknesses and advantages: 
Table 29: Three Places Option

\begin{tabular}{|c|c|c|c|}
\hline NO & $\begin{array}{l}\text { PLACES TO } \\
\text { TRANSACT }\end{array}$ & WEAKNESS & ADVANTAGE \\
\hline 1 & $\begin{array}{l}\text { At Office/ Walk- } \\
\text { In }\end{array}$ & $\begin{array}{l}\text { - Costly investments and } \\
\text { high operational costs } \\
\text { - Limited distance/area } \\
\text { - Insufficient number of } \\
\text { office }\end{array}$ & $\begin{array}{l}\text { Give confidence to new } \\
\text { customers }\end{array}$ \\
\hline 2 & $\begin{array}{l}\text { By Phone/ } \\
\text { Whatsapp }\end{array}$ & $\begin{array}{l}\text { - Limited communication } \\
\text { only voice, text, and } \\
\text { photos } \\
\text { History cannot be } \\
\text { recorded properly }\end{array}$ & - $\quad$ Everyone can do it \\
\hline 3 & $\begin{array}{l}\text { Via Mobile } \\
\text { Application }\end{array}$ & $\begin{array}{l}\text { The initial investment is } \\
\text { expensive by making } \\
\text { Mobile Applications }\end{array}$ & 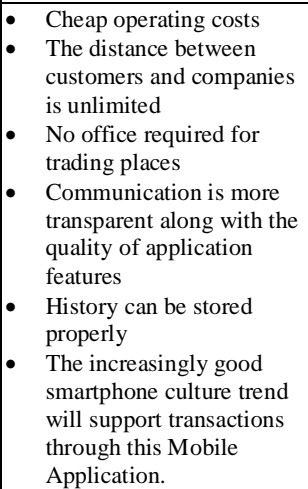 \\
\hline
\end{tabular}

Visible in the Table 29 above, the place of transaction in a mobile application has more benefits than at the office and by phone/WhatsApp. This new business is still looking for popularity; all three places above will be executed altogether.

For an office, it will be the preferred location where the customer segment population that has been specified is many small micro enterprises (SME) entrepreneurs are the selected segments. The traditional market is rated to be an excellent location to meet this customer segment. The office location will be determined close to the market. Determining the place of a business is one of the most important because often the success of an effort depends on the selection of the location of the company.

Based on Indonesia's statistical data 2018 issued by the central Statistic (BPS), the top 5 (five) population density per province is: DKI Jakarta $\left(15,624\right.$ people per $\left.\mathrm{km}^{2}\right)$, West Java $\left(1,358\right.$ people per $\left.\mathrm{km}^{2}\right)$, Banten $\left(1,288\right.$ people per $\left.\mathrm{km}^{2}\right)$, in Yogyakarta $\left(1,201\right.$ people per $\left.\mathrm{km}^{2}\right)$, and Central Java $(1,044$ people per $\mathrm{km}^{2}$ ). Based on 2016 economic census (Sensus Ekonomi 2016) data about the number of SME in Indonesia, issued by BPS: (see Table 30 below).

Table 30: The Top Five SME per Provinces in Indonesia

\begin{tabular}{|r|l|r|r|r|r|r|}
\hline NO & PROVINCE & $\begin{array}{c}\text { SQUARE } \\
\text { AREA } \\
\text { KM }\end{array}$ & $\begin{array}{c}\text { SME } \\
\text { NUMBERS }\end{array}$ & $\begin{array}{c}\text { SME } \\
\text { NUMBERS } \\
\text { PER } \\
\text { SQUARE } \\
\text { AREA }\end{array}$ & $\begin{array}{c}\text { REVENUES } \\
\text { II } \\
\text { BILLION } \\
\text { RUPIAHS) }\end{array}$ & $\begin{array}{c}\text { REVENUES } \\
\text { PER } \\
\text { SQUARE } \\
\text { AREA }\end{array}$ \\
\hline 1 & DKI Jakarta & 664 & $1,151,080$ & 1733 & 334.417 & 503 \\
\hline 2 & DI Yogyakarta & 3.133 & 521,011 & 166 & 83,543 & 26 \\
\hline 3 & West Java & 35.377 & $4,545,874$ & 128 & 916,322 & 25 \\
\hline 4 & Banten & 9.662 & 943,922 & 97 & 208,429 & 21 \\
\hline 5 & Central Java & 32.800 & $4,105,917$ & 125 & 672,672 & 20 \\
\hline & INDONESIA & $\mathbf{1 . 9 1 3 5 7 8}$ & $\mathbf{2 6 , 0 7 3 , 6 8 9}$ & $\mathbf{1 3}$ & $\mathbf{5 , 1 0 6 , 4 8 8}$ & $\mathbf{2}$ \\
\hline
\end{tabular}

From the two tables above, obtained 5 (five) provinces interesting to be the location of the business, and DKI Jakarta is the best. Taking into consideration the suburbs of DKI Jakarta with its relatively lower property values and the same as rent values and human resources (HR) readiness for the region, it was decided to choose a new business location in Jalan Joglo Raya West Jakarta.

The office building can be property rights or rental building. In addition to the two options above, there is currently a shared office option. There are several advantages and disadvantages of the three business options. In this research, a second option is chosen, the office rental business, with consideration:

1. No need for high initial deposit capital

2. Initial investment should not be too large

3. Able to select a business place with rental cost adjusted to the growth of business revenue

4. Although the selection of the location in the beginning already learned the market to be achieved, if there is a market company or the wrong initial assessment, with the lease will facilitate the move more suitable location

\subsubsection{Promotion}

Promotional activities will be done offline with the banner installation of several crowded locations, the division of brochures in front of the office and the local-markets; and online via social media such as Instagram, Twitter, Facebook, line, and many visited websites. Promotion program will be given in the form of a member-get-member program to get recommendations from old customers, and rental bonus program at certain events. With the option of daily rental (in addition to the weekly and monthly rental options), is a promotion so that potential customers can try the motor and adjust to its business, whether the specifications of the vehicle to be rented match the business.

\subsubsection{Physical Evidence}

To prove that this marketing strategy has been successful in achieving the target market that was shot, data collection, and data analysis required:

1. Customer feedback. After the lease period expires, the customer will be given a survey through the application or by phone from customer care. Which one of the questions in the survey, there is customer feedback on our marketing program.

2. In the business process, all forms of compensation to customers must be through customer care, so that customer care can record its history on the company's information system, one of which is useful as a proof of the effectiveness of the company's marketing strategy. 
3. The company may require customers to expose their customers ' photos or videos by using this rental motor on their social media, as a proof of customer loyalty to the company.

4. Member-get-member promotion program can also be proof of the success of a marketing strategy and service level that has been given to customers.

\subsubsection{Process}

The process is an important factor in marketing strategy. The success process is measured from:

1. The speed of delivery of services to customers, namely from the booking to the motor received by the customer, among which there is a series of processes that go through. The sooner the time is given, the better the process has been worked.

2. How many complaints from customers to the process can be a measure of the success process.

3. Speed of time in giving a response to customer complaints is also a measure of the success process.

\subsubsection{Key Performance Indicators}

The KPI is established with the following criterion (see Table 31).

Table 31: Customer Perspective KPI

\begin{tabular}{|c|c|c|c|}
\hline NO & $\begin{array}{l}\text { STRATEGIC } \\
\text { OBJECTIVES }\end{array}$ & MEASURES & TARGETS \\
\hline 1 & $\begin{array}{l}\text { Increase Customer } \\
\text { Satisfaction }\end{array}$ & $\begin{array}{l}\text { - Customer satisfaction } \\
\text { Questioner } \\
\text { - Customer feedback }\end{array}$ & Better score than last year \\
\hline 2 & $\begin{array}{l}\text { Increase Customer } \\
\text { Loyalty }\end{array}$ & $\begin{array}{l}\text { Number of existing customers } \\
\text { who reorder/renew the rental } \\
\text { contract }\end{array}$ & $50 \%$ growth per year \\
\hline 3 & $\begin{array}{l}\text { Increase Sales Revenue } \\
\text { Per Customer }\end{array}$ & $\begin{array}{l}\text { Average sales revenue per } \\
\text { customer }\end{array}$ & $10 \%$ growth per year \\
\hline 4 & Increase New Customers & Number of new customers & $50 \%$ growth per year \\
\hline 5 & $\begin{array}{l}\text { Competitive Pricing dan } \\
\text { Product Offering }\end{array}$ & $\begin{array}{l}\text { Price comparisons and product } \\
\text { variations }\end{array}$ & Better then competitors \\
\hline 6 & High-Quality Services & \begin{tabular}{|cl} 
SERVQUAL & dimension: \\
1. & Tangible \\
2. & Reliability \\
3. & Responsiveness \\
4. & Assurance \\
5. & Empathy \\
\end{tabular} & Decrease gap scores \\
\hline & Be a Market Leader & Survey rental market & Increase market share $p$ \\
\hline
\end{tabular}

\subsection{BSC - Internal Business Processes}

\section{Perspective}

\subsubsection{Organization Structure}

The motorcycle rental business will be made to have a standalone and separate PT XYZ organizational structure.

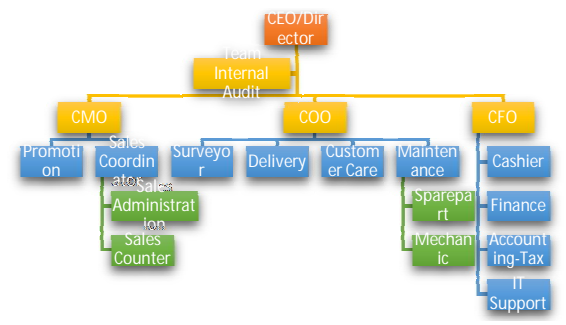

Figure 3: Organization Structure for New Business
This business will have its legal entity with the majority stake is the shares of PT. XYZ as its parent organization (see Figure 3).

\subsubsection{Job Description}

Job descriptions of each function in the structure of the motorcycle rental business organization are as follows: (see Table 32)

Table 32: Jobs Description

\begin{tabular}{|c|c|c|c|}
\hline & JOB NAME & JOB DESCRIPTION & REQUIREMENTS \\
\hline 1 & $\begin{array}{l}\text { CEO (Chief } \\
\text { Executive } \\
\text { Officer) }\end{array}$ & $\begin{array}{l}\text { Serving as coordinator, } \\
\text { communicator, decision-maker, } \\
\text { leader, manager, and executor in } \\
\text { running the company and } \\
\text { responsible for the formulation } \\
\text { of the company's strategy and } \\
\text { success in achieving its mission, } \\
\text { vision, and determining and } \\
\text { deciding on the company's } \\
\text { highest roles and policies. }\end{array}$ & $\begin{array}{l}\text { 1. } \begin{array}{l}\text { Experience in the field of } \\
\text { automotive dealers at least } \\
\text { ten years }\end{array} \\
\text { 2. } \begin{array}{l}\text { Minimum S2-degree in this } \\
\text { business-related field }\end{array} \\
\text { 3. Have competence in } \\
\text { various areas related to this } \\
\text { business } \\
\text { 4. } \begin{array}{l}\text { Good leadership and } \\
\text { management skills }\end{array}\end{array}$ \\
\hline 2 & $\begin{array}{l}\text { Internal } \\
\text { Audit }\end{array}$ & $\begin{array}{l}\text { In charge of internal audit } \\
\text { function to assist the CEO in } \\
\text { terms of supervisory }\end{array}$ & $\begin{array}{l}\text { 1. Has competence as Internal } \\
\text { Audit } \\
\text { 2. Can be independent }\end{array}$ \\
\hline 3 & $\begin{array}{l}\text { CMO (Chief } \\
\text { Marketing } \\
\text { Officer) }\end{array}$ & $\begin{array}{l}\text { Determining marketing } \\
\text { strategies and setting rental } \\
\text { revenue targets, as well as } \\
\text { maintaining rental revenue } \\
\text { growth annually. }\end{array}$ & $\begin{array}{l}\text { 1. Minimum marketing } \\
\text { experience five years } \\
\text { 2. Minimum S1-degree in } \\
\text { marketing or automotive } \\
\text { field } \\
\text { 3. Have competence in } \\
\text { various areas related to this } \\
\text { business } \\
\text { 4. Has a pleasant personality } \\
\text { and can give motivation to } \\
\text { his marketing team }\end{array}$ \\
\hline 4 & $\begin{array}{l}\text { COO }(\text { Chief } \\
\text { Operating } \\
\text { Officer })\end{array}$ & $\begin{array}{l}\text { Managing internal activities } \\
\text { within the company, managing } \\
\text { the core business, ensuring that } \\
\text { all } \\
\text { operational activities of the } \\
\text { company running well. }\end{array}$ & $\begin{array}{l}\text { 1. Experience in the field of } \\
\text { automotive workshop five } \\
\text { years minimum } \\
\text { 2. Have competence in } \\
\text { various areas related to this } \\
\text { business } \\
\text { 3. Minimum S1-degree in a } \\
\text { machine or automotive } \\
\text { field }\end{array}$ \\
\hline 5 & $\begin{array}{l}\text { CFO (Chief } \\
\text { Financial } \\
\text { Officer) }\end{array}$ & $\begin{array}{l}\text { Dealing with the various types of } \\
\text { financial risks facing the } \\
\text { company, coordinate financial } \\
\text { activity and collaborate the team } \\
\text { to achieve the optimal business } \\
\text { outcomes of the implementation } \\
\text { of all activities to protect the } \\
\text { company's assets } \\
\text { and company Investments. }\end{array}$ & $\begin{array}{l}\text { 1. Minimum } 5 \text { years of } \\
\text { financial experience } \\
\text { 2. Minimum S1-degree in } \\
\text { finance or accounting } \\
\text { 3. Have competence in } \\
\text { various areas related to this } \\
\text { business } \\
\text { 4. Be honest and get good } \\
\text { references in the financial } \\
\text { field }\end{array}$ \\
\hline 6 & Promotion & $\begin{array}{l}\text { Promoting company name, a } \\
\text { product brand of motorcycle } \\
\text { leased, and marketing strategy. } \\
\text { Can create promotional } \\
\text { strategies on offline and online } \\
\text { media. Can collaborate with } \\
\text { dealers, ATPM, and motorcycle } \\
\text { community in conducting } \\
\text { promotions. }\end{array}$ & $\begin{array}{l}\text { 1. Experience in the field of } \\
\text { rental marketing at least } \\
\text { two years } \\
\text { 2. Minimum D3-degree all } \\
\text { fields education } \\
\text { 3. Creative and always have a } \\
\text { new idea }\end{array}$ \\
\hline 7 & \begin{tabular}{|l|} 
Sales \\
Coordinator
\end{tabular} & $\begin{array}{l}\text { Marketing the product, can } \\
\text { provide training and motivation } \\
\text { to selling, and coordinate the } \\
\text { whole marketing team. }\end{array}$ & $\begin{array}{l}\text { 1. Experience in the field of } \\
\text { rental marketing at least } \\
\text { one year and always reach } \\
\text { the target given } \\
\text { 2. Minimum D3-degree all } \\
\text { fields education } \\
\text { 3. Can organize product } \\
\text { knowledge training and } \\
\text { salesmanship education }\end{array}$ \\
\hline
\end{tabular}




\begin{tabular}{|c|c|c|c|}
\hline & JOB NAME & JOB DESCRIPTION & REQUIREMENTS \\
\hline 8 & $\begin{array}{l}\text { Sales } \\
\text { Administrati } \\
\text { on }\end{array}$ & $\begin{array}{l}\text { Recording business transactions, } \\
\text { recording the delivery and } \\
\text { withdrawal process, record } \\
\text { customer payments, record } \\
\text { assets maintenance, record } \\
\text { inventory, and conditions to be } \\
\text { ready for rent. }\end{array}$ & $\begin{array}{l}\text { 1. Minimum D3 all fields } \\
\text { education } \\
\text { 2. Mastering Microsoft Excel } \\
\text { and Microsoft Word } \\
\text { applications } \\
\text { 3. Nice, neat and thorough } \\
\text { writing }\end{array}$ \\
\hline 9 & \begin{tabular}{|l} 
Sales \\
Counter
\end{tabular} & $\begin{array}{l}\text { Serving the prospective } \\
\text { customers who come to the } \\
\text { showroom, by phone, or through } \\
\text { social media, and directing } \\
\text { potential customers to make } \\
\text { transactions and loyal to the } \\
\text { company }\end{array}$ & $\begin{array}{l}\text { 1. Minimum D3-degree all } \\
\text { fields education } \\
\text { 2. Attractive, friendly, and } \\
\text { good-looking }\end{array}$ \\
\hline 10 & Surveyor & $\begin{array}{l}\text { Surveying prospective } \\
\text { customers, by visiting the } \\
\text { residence or place of business, } \\
\text { and making survey reports }\end{array}$ & $\begin{array}{l}\text { 1. Minimum D3-degree all } \\
\text { fields education } \\
\text { 2. Have a firm stance in the } \\
\text { establishment, } \\
\text { independent, and not easily } \\
\text { influenced }\end{array}$ \\
\hline 11 & Delivery & $\begin{array}{l}\text { In charge of sending motorcycles } \\
\text { from the company's warehouse } \\
\text { to the customer's home or } \\
\text { business locations, as well as } \\
\text { vice versa. Manage the } \\
\text { operational cars maintenance, } \\
\text { repairment, vehicle licenses, and } \\
\text { insurances }\end{array}$ & $\begin{array}{l}\text { 1. Education D3 of all fields } \\
\text { 2. Has rider license SIM A } \\
\text { and SIM C } \\
\text { 3. Male gender } \\
\text { 4. Strong-body has no history } \\
\text { of severe pain }\end{array}$ \\
\hline 12 & $\begin{array}{l}\text { Customer } \\
\text { Care }\end{array}$ & $\begin{array}{l}\text { Responding to the customer's } \\
\text { questions and complaints by } \\
\text { phone, live chat, and social } \\
\text { media, can make the right } \\
\text { solution for customer's problems }\end{array}$ & 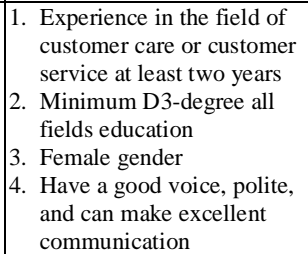 \\
\hline 13 & Maintenance & $\begin{array}{l}\text { Managing the maintenance of all } \\
\text { motorcycle and car inventory of } \\
\text { the company, keep all the } \\
\text { motorcycle and car inventory } \\
\text { ready on the road, arrange a } \\
\text { maintenance visit schedule, and } \\
\text { can coordinate the team }\end{array}$ & $\begin{array}{l}\text { 1. Experience in workshop } \\
\text { field at least five years } \\
\text { 2. Have competence in the } \\
\text { field of motorcycles and } \\
\text { cars maintenance } \\
\text { 3. Minimum education D3- } \\
\text { degree in the field of } \\
\text { machinery or automotive } \\
\text { 4. Male gender } \\
\text { 5. Have leadership and can do } \\
\text { motorcycle repairment } \\
\text { training }\end{array}$ \\
\hline 14 & Sparepart & $\begin{array}{l}\text { Controlling inventory of } \\
\text { motorcycle's spare parts and oils } \\
\text { well }\end{array}$ & $\begin{array}{l}\text { 1. Experience in the field of } \\
\text { motorcycle spare parts at } \\
\text { least two years } \\
\text { 2. Minimum D3-degree } \\
\text { education in all fields } \\
\text { 3. Male gender } \\
\text { 4. Mastering Microsoft Excel } \\
\text { and Microsoft Word } \\
\text { 5. Can work neatly and } \\
\text { thoroughly }\end{array}$ \\
\hline 15 & Mechanic & $\begin{array}{l}\text { Repairing motorcycles in the } \\
\text { company's workshop or at } \\
\text { customers location (home } \\
\text { service), and can explaining the } \\
\text { damage of motorcycle to } \\
\text { customers }\end{array}$ & $\begin{array}{l}\text { 1. Experience in the field of } \\
\text { repairing motorcycle two } \\
\text { years minimum } \\
\text { 2. Minimal STM or SMK } \\
\text { automotive education } \\
\text { 3. Male gender } \\
\text { 4. Has competence in the } \\
\text { field of mechanic }\end{array}$ \\
\hline 16 & Cashier & $\begin{array}{l}\text { Managing outgoing funds in the } \\
\text { company, maintaining the } \\
\text { suitability of funds coming out } \\
\text { with supporting evidence, } \\
\text { managing the financial records } \\
\text { well. Especially for the central } \\
\text { cashier, has an additional duty to } \\
\text { coordinate the needs of branches' } \\
\text { petty cash, and to reconcile } \\
\text { transfer of funds between the }\end{array}$ & $\begin{array}{l}\text { 1. Cashier experience at least } \\
\text { two years } \\
\text { 2. Minimum D3-degree in } \\
\text { Finance } \\
\text { 3. Have an honest, firm, } \\
\text { thorough, and independent } \\
\text { personality }\end{array}$ \\
\hline
\end{tabular}

\begin{tabular}{|c|c|c|c|}
\hline & JOB NAME & JOB DESCRIPTION & REQUIREMENTS \\
\hline & & $\begin{array}{l}\text { braches bank accounts and head } \\
\text { office }\end{array}$ & \\
\hline 17 & Finance & $\begin{array}{l}\text { Managing the company's funds, } \\
\text { such as cash flow, revenue } \\
\text { receipts, payment obligations, } \\
\text { expenditures, and ensuring that } \\
\text { all fund mutations are correct } \\
\text { based on their evidence. } \\
\text { Purchasing the company needs } \\
\text { on request from each division, } \\
\text { analyzing suppliers, and } \\
\text { ensuring the fairness of price and } \\
\text { quality of goods purchased. }\end{array}$ & $\begin{array}{l}\text { 1. Minimum } 5 \text { years of } \\
\text { financial experience } \\
\text { 2. Minimum S1-degree } \\
\text { education in finance } \\
\text { 3. Female gender } \\
\text { 4. Has good working } \\
\text { references in previous } \\
\text { companies and can be } \\
\text { confirmed } \\
\text { 5. Have an honest, firm, } \\
\text { thorough, and independent } \\
\text { personality }\end{array}$ \\
\hline 18 & $\begin{array}{l}\text { Accounting- } \\
\text { Tax }\end{array}$ & $\begin{array}{l}\text { Presenting a monthly financial } \\
\text { statement that can describe the } \\
\text { actual condition of the company, } \\
\text { and ensure that the company } \\
\text { adheres to all applicable taxation } \\
\text { regulations }\end{array}$ & $\begin{array}{l}\text { 1. Experience in accounting } \\
\text { two years minimum } \\
\text { 2. Minimum S1 degree in } \\
\text { accounting } \\
\text { 3. Has competency in } \\
\text { accounting and taxation } \\
\text { 4. Have a thorough and } \\
\text { critical attitude }\end{array}$ \\
\hline 19 & IT Support & $\begin{array}{l}\text { Maintaining all the information } \\
\text { technology assets, maintaining } \\
\text { good cooperation with all IT } \\
\text { vendors, and can serve the needs } \\
\text { of other divisions for the } \\
\text { information technology }\end{array}$ & $\begin{array}{l}\text { 1. Experience in the IT field } \\
\text { at least one year } \\
\text { 2. Minimum S1-degree in IT } \\
\text { education } \\
\text { 3. Has competency in IT field }\end{array}$ \\
\hline
\end{tabular}

\subsubsection{Business Process Model}

In conducting operational activities, business process, standard operating procedure, and work instruction are required. Business process using terms and formatting agreed in Business Process Model Notation. There are 4 (four) major business processes on this motorcycle rental business. Here is the list of the main processes. In the next section, each of these critical processes will be detailed in the flowchart diagram using the Bizagi Modeler tools.

- New Rental Process

- Application Booking

- Periodic Maintenance

- Repairment

The details of business process model is shown in Figure 4, 5,6 , and 7 .

\subsubsection{New Rental Process}

This process starts from customer booking rental motorcycle, feasibility survey, approval, or rejection until the customer gets the motorcycle and get lease contract. 


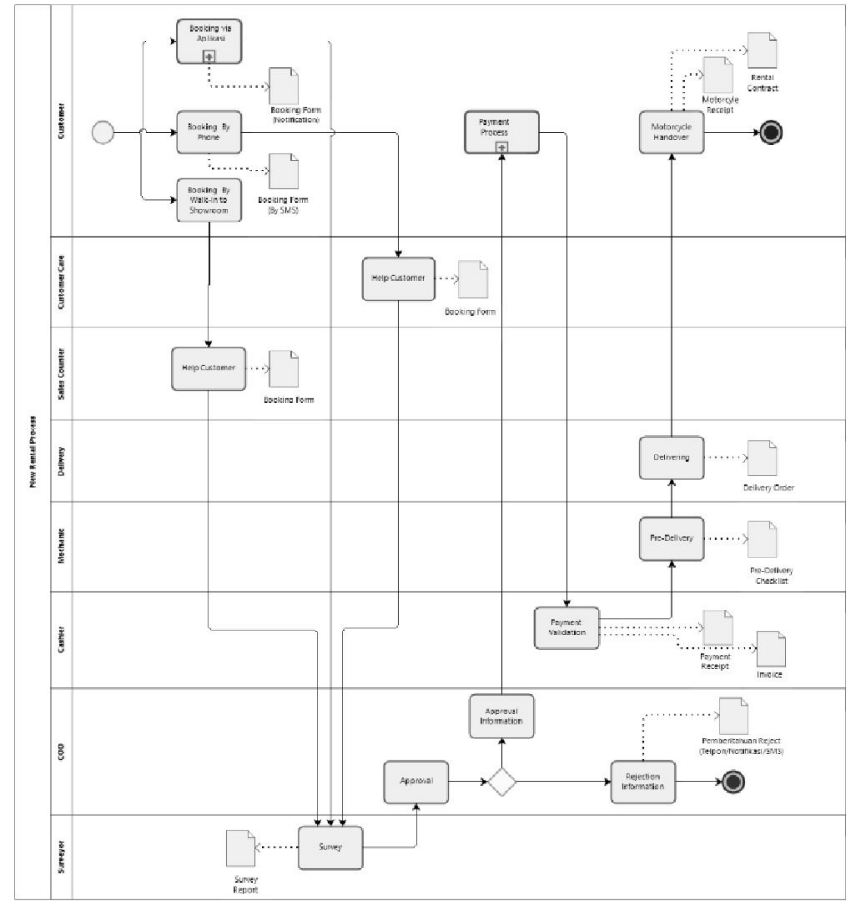

Figure 4: New Rental BPM

\subsubsection{Application Booking Process}

In the booking process, there is an alternative to booking via the app. In this process, the prospective customer will log in to the app, then choose the motorcycle model, select the term of payment option, set the rent period, determine the location survey and time, until the lease payment after approval. This process uses an android-based mobile application.

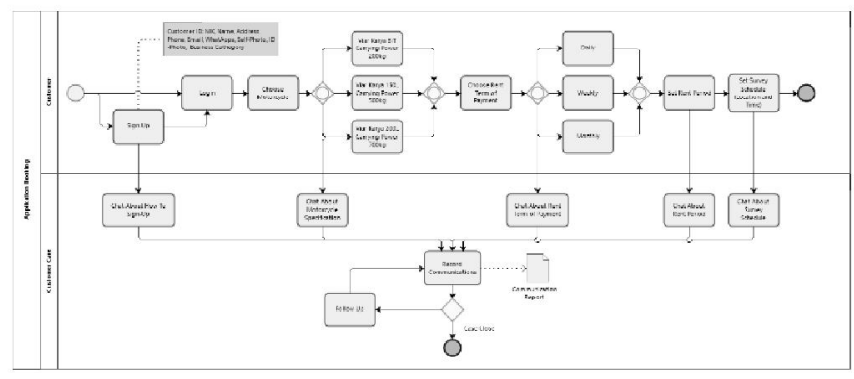

Figure 5: Application Booking BPM

\subsubsection{Periodic Maintenance Process}

All motorized vehicles are required to maintain periodically, according to the type of motorcycles and how many kilometers the motor has traveled. The periodic motorcycle maintenance process will be done by Mechanic and follow pre-defined treatment packages. If this process is not done correctly, there will be losses to the company, because the motorcycle cannot be able to be operated and rented.

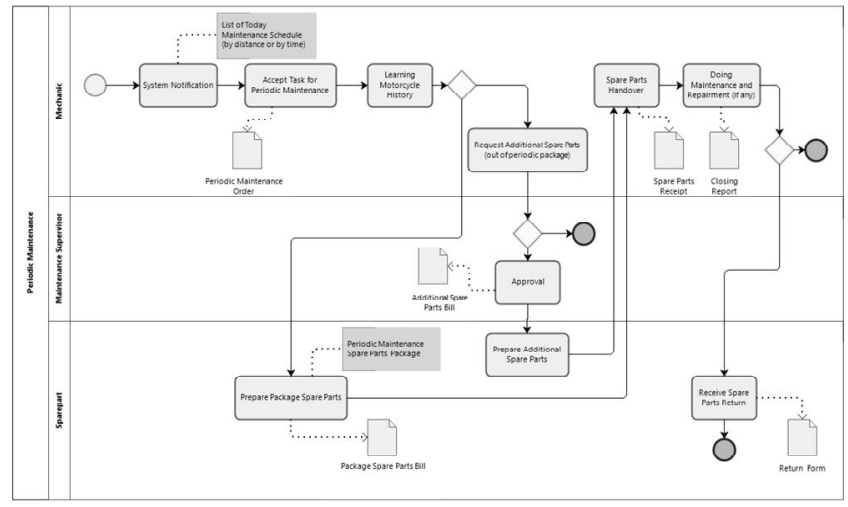

Figure 6: Periodic Maintenance BPM

\subsubsection{Repairment Process}

The motorcycle repair process differs from periodic maintenance. Repairment process if there is damage in the motorcycles

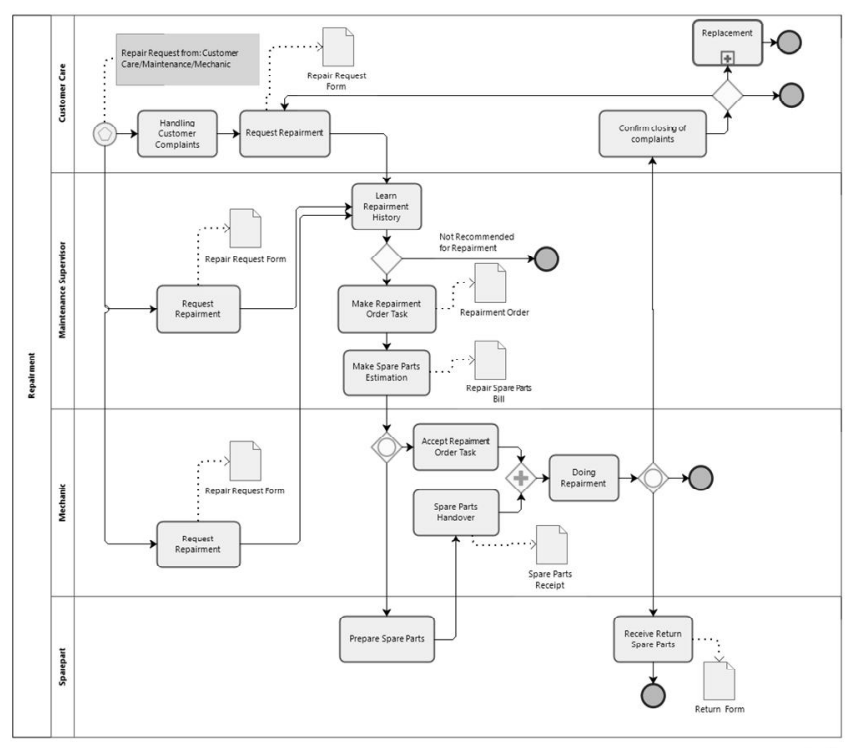

Figure 7: Repairment BPM.

\subsubsection{Key Performance Indicators}

The business internal perspectives for KPI is shown Table 33. 
Table 33: Business Internal Process Perspective KPI

\begin{tabular}{|c|c|c|c|}
\hline \multicolumn{2}{|c|}{\begin{tabular}{|c|c|} 
NO & $\begin{array}{c}\text { STRATEGIC } \\
\text { OBJECTIVES }\end{array}$ \\
\end{tabular}} & MEASURES & TARGETS \\
\hline - & Speed of service time & $\begin{array}{l}\text { Range time from booking to motorcycle } \\
\text { handover }\end{array}$ & Average faster than last year \\
\hline 2 & Customer service process & $\begin{array}{ll}\text { 1. } & \text { Number of customer complaints } \\
\text { 2. } & \text { Number of motorcycle } \\
\text { 3. } & \text { replacement } \\
\text { Compensation value }\end{array}$ & Decreased then last year \\
\hline 3 & $\begin{array}{l}\text { Speed of decision } \\
\text { making }\end{array}$ & $\begin{array}{ll}\text { Range time approval/rejection: } \\
1 . & \text { survey } \\
2 . & \text { compensation } \\
\text { 3. } & \text { payment validation } \\
4 . & \text { complaint response }\end{array}$ & Always maintain \\
\hline 4 & Employee performance & Average employee KPI scores & Better \\
\hline 5 & Monitoring dan Control & $\begin{array}{l}\text { Number of findings per levels: major, } \\
\text { minor, and opportunity for } \\
\text { improvement/OFI }\end{array}$ & Better \\
\hline 6 & \begin{tabular}{|l|} 
Financial Information \\
\end{tabular} & $\begin{array}{|ll|}\text { 1. } & \text { Financial Report Availability } \\
\text { 2. } & \text { Financial Report Confidentiality } \\
\text { 3. } & \text { Financial Report Accountability } \\
\text { 4. } & \text { Financial Report Integrity }\end{array}$ & \begin{tabular}{|ll} 
1. & On-time reporting \\
2. & Zero accident about \\
& financial information \\
& security \\
3. & No major findings \\
& from internal audit \\
& about financial report \\
4. & contents \\
4. & Completely reporting \\
\end{tabular} \\
\hline 7 & Internal Reporting & Timeliness of internal reporting & Never exceed the deadline \\
\hline 8 & $\begin{array}{l}\text { Standard Operating } \\
\text { Procedure (SOP) } \\
\text { Implementation }\end{array}$ & Conformity with SOP & $\begin{array}{l}\text { No major findings from } \\
\text { internal audit about SOP in } \\
\text { daily implementation }\end{array}$ \\
\hline
\end{tabular}

\subsection{BSC - Learning And Growth Perspective}

\subsubsection{Risk Management Plan}

Because the business is still in the form of design and has not been implemented, risk management is the identification and planning.

\subsubsection{Risk Criteria}

To identify the risks available in this motorcycle rental business and to measure the risk level, it is necessary to determine risk criteria first. Risk acceptance criteria will be calculated with the formula:

\section{Level of Risk $=$ Likelihood X Severity X Asset Value}

Likelihood or probability of occurrence of risk is determined by 3 (three) values: 1 (Low), 2 (Medium), 3 (high). The value is 1 (one) describes a rare risk event with a limitation of fewer than two occurrences within one year, the value is 2 (two) describing a risk event between 2-5 events within one year, while the value is 3 (three) describes a risk event occurring more than five times in one year of assessment.

Severity of impact or consequence set by 3 (three) values: 1 (Low), 2 (Medium), and 3 (high). A value of 1 for risk events resulting in a financial loss of less than Rp5,000,000 (five million rupiahs), including losses due to missadministration that does not incur financial losses. The value of 2 for risk events with a financial capacity of Rp5,000,000 up to Rp50,000,000. A value of 3 for risk events resulting in financial loss above Rp50,000,000 and/or loss of corporate reputation and/or legal damages. Although a risk event does not result in financial losses above fifty million rupiahs, it affects the reputation of the company's good name or affects the legal disclaimer for the company, the value of severity is 3 (three).

Asset value or sensitivity is determined by combining three aspects of information security: C (Confidentiality), A (Availability), and I (Integrity). Confidentiality, availability, and integrity, each has a value of 1-3, with 1 (Low), 2 (Medium), and 3 (high). The Asset value is the sum of all three CIA values.

With the formula above, the level of risk, the lowest risk level is 3 , and the highest risk level is 81 . So the range level of risk is defined as:

$$
\begin{aligned}
& \text { Low }=3-20 \\
& \text { Medium }=21-40 \\
& \text { Height }=41-81
\end{aligned}
$$

For a level of risk of 41 or more, the company will create a risk treatment plan. Because this motorcycle rental business is still in design, Risk Assessment and Risk Treatment Plan can not be established, and it will be done once a year.

\subsubsection{Assets Register}

This motor rental business is identified as having 20 (twenty) assets that have different values from the confidentiality, integrity, and availability. The asset value of each asset can be described as follows: (see Table 34).

Table 34: Assets Register

\begin{tabular}{|c|l|l|l|l|l|l|}
\hline $\begin{array}{c}\text { ASSET } \\
\text { CODE }\end{array}$ & \multicolumn{1}{|c|}{ ASSET NAME } & RISK OWNER & C & I & A & ASSET VALUE \\
\hline A01 & Transactions Data & Marketing Division & 2 & 2 & 1 & 5 \\
\hline A02 & Rent Price Strategy & Marketing Division & 1 & 1 & 1 & 3 \\
\hline A03 & Promotion Strategy & Marketing Division & 1 & 1 & 1 & 3 \\
\hline A04 & Marketing Files Archive & Marketing Division & 1 & 1 & 1 & 3 \\
\hline B01 & Spare Parts Inventory & Operation Division & 1 & 2 & 3 & 6 \\
\hline B02 & Motorcycles Asset & Operation Division & 1 & 1 & 3 & 5 \\
\hline B03 & Delivery Cars & Operation Division & 1 & 1 & 3 & 5 \\
\hline B04 & Workshop Equipments & Operation Division & 1 & 1 & 3 & 5 \\
\hline B05 & Operation Files Archive & Operation Division & 1 & 1 & 1 & 3 \\
\hline C01 & Company Funds & Finance Division & 3 & 3 & 3 & 9 \\
\hline C02 & Financial Statements & Finance Division & 3 & 3 & 2 & 8 \\
\hline C03 & Tax Evidences & Finance Division & 2 & 3 & 2 & 7 \\
\hline C04 & Financial Files Archive & Finance Division & 3 & 3 & 2 & 7 \\
\hline D01 & Company Database & IT Division & 3 & 3 & 3 & 9 \\
\hline D02 & Software Applications & IT Division & 1 & 1 & 3 & 5 \\
\hline D03 & Server (if any) & IT Division & 1 & 1 & 3 & 5 \\
\hline D04 & IT Devices & IT Division & 1 & 1 & 3 & 5 \\
\hline E01 & Customers Data & All Division & 2 & 3 & 3 & 8 \\
\hline E02 & Employees Data & All Division & 2 & 2 & 1 & 5 \\
\hline E03 & Office Furnitures & All Division & 1 & 1 & 1 & 3 \\
\hline
\end{tabular}

$=$

Asset value is determined by the sum of $\mathrm{C}$ (Confidentiality), A (Availability), and I (Integrity). Assessment of CIA value depends on the risk appetite of each company, can be evaluated and corrected periodically. 


\subsubsection{Risk Register}

Here are some risk occurrences/events that can be estimated will be happening in this business model, and the controls that can be done when the business is running (see Table 35).

Table 35: Risk Register

\begin{tabular}{|c|c|c|c|c|}
\hline $\begin{array}{l}\text { ASSET } \\
\text { CODE }\end{array}$ & ASSET NAME & \begin{tabular}{|l|} 
RISK \\
CODE \\
\end{tabular} & RISK NAME & CONTROLS \\
\hline A01 & Transactions Data & R01 & $\begin{array}{l}\text { Marketing creates } \\
\text { fake transaction data }\end{array}$ & $\begin{array}{l}\text { Customer Care and Finance } \\
\text { personnel is required to confirm each } \\
\text { transaction }\end{array}$ \\
\hline A02 & Rent Price Strategy & R02 & \begin{tabular}{|l|} 
Rental price \\
calculations are \\
known to competitors
\end{tabular} & - \\
\hline A03 & Promotion Strategy & R03 & $\begin{array}{l}\text { Promotion strategies } \\
\text { imitated competitors }\end{array}$ & - \\
\hline A04 & $\begin{array}{l}\text { Marketing Files } \\
\text { Archive }\end{array}$ & R04 & $\begin{array}{l}\text { Marketing files } \\
\text { missing }\end{array}$ & $\begin{array}{l}\text { Digital backup; Documented } \\
\text { information management SOP }\end{array}$ \\
\hline \multirow[t]{2}{*}{ B01 } & \multirow[t]{2}{*}{ Spare Parts Inventory } & R05 & $\begin{array}{l}\text { Spare parts missing } \\
\text { in warehouse }\end{array}$ & Spare parts difference stock SOP \\
\hline & & R06 & $\begin{array}{l}\text { Spare parts lost when } \\
\text { taken by Mechanic }\end{array}$ & $\begin{array}{l}\text { Spare parts loss responsibility and } \\
\text { sanctions SOP }\end{array}$ \\
\hline \multirow[t]{3}{*}{ B02 } & \multirow[t]{3}{*}{ Motorcycles Asset } & R07 & $\begin{array}{l}\text { Motorcycle missing } \\
\text { in the warehouse }\end{array}$ & $\begin{array}{l}\text { Warehouse security system; } \\
\text { Motorcycle insurance }\end{array}$ \\
\hline & & R08 & $\begin{array}{l}\text { Motorcycle lost when } \\
\text { rented }\end{array}$ & $\begin{array}{l}\text { In contracts include legal and } \\
\text { administrative sanctions; Motorcycle } \\
\text { insurance }\end{array}$ \\
\hline & & R09 & $\begin{array}{l}\text { Motorcycle damage } \\
\text { when rented }\end{array}$ & $\begin{array}{l}\text { Pre-delivery Check-Up SOP; } \\
\text { Damages Investigation SOP }\end{array}$ \\
\hline \multirow[t]{2}{*}{ B03 } & \multirow[t]{2}{*}{ Delivery Cars } & R10 & Lost car & $\begin{array}{l}\text { Car insurance; Operational cars } \\
\text { responsibility and sanctions SOP }\end{array}$ \\
\hline & & R11 & Damage car & $\begin{array}{l}\text { Car insurance; Fixed assets damage } \\
\text { and loss SOP }\end{array}$ \\
\hline B04 & $\begin{array}{l}\text { Workshop } \\
\text { Equipment }\end{array}$ & R12 & Tools lost or damage & $\begin{array}{l}\text { Control workshop tools condition } \\
\text { periodically }\end{array}$ \\
\hline B05 & $\begin{array}{l}\text { Operation Files } \\
\text { Archive }\end{array}$ & R13 & $\begin{array}{l}\text { Operational files } \\
\text { archive missing }\end{array}$ & $\begin{array}{l}\text { Digital backup; Documented } \\
\text { information management SOP }\end{array}$ \\
\hline $\mathrm{C} 01$ & Company Funds & R14 & Fraud & Anti-fraud SOP \\
\hline $\mathrm{C} 02$ & Financial Statements & R15 & $\begin{array}{l}\text { Financial statements } \\
\text { viewed and/or used } \\
\text { by unauthorized } \\
\text { parties }\end{array}$ & Confidentiality of company data SOP \\
\hline $\mathrm{C} 03$ & Tax Evidence & R16 & $\begin{array}{l}\text { Tax reports viewed } \\
\text { and/or used by } \\
\text { unauthorized parties }\end{array}$ & $\begin{array}{l}\text { Digital backup; Confidentiality of } \\
\text { company data SOP }\end{array}$ \\
\hline $\mathrm{C} 04$ & $\begin{array}{l}\text { Financial Files } \\
\text { Archive }\end{array}$ & R17 & \begin{tabular}{|l|} 
Financial files \\
missing or \\
incomplete archive
\end{tabular} & $\begin{array}{l}\text { Confidentiality of company data } \\
\text { SOP; Documented information } \\
\text { management SOP }\end{array}$ \\
\hline D01 & Company Database & R18 & $\begin{array}{l}\text { Database } \\
\text { corrupt/damage }\end{array}$ & Cloud Backup \\
\hline D02 & $\begin{array}{l}\text { Software } \\
\text { Applications }\end{array}$ & R19 & Application down & IT Vendor SLA \\
\hline D03 & Server (if any) & R20 & $\begin{array}{l}\text { Corrupted/Missing } \\
\text { Server }\end{array}$ & Redundant cloud server \\
\hline D04 & IT Devices & R21 & Laptop inventory lost & Fixed assets damage and loss SOP \\
\hline \multirow[t]{2}{*}{ E01 } & \multirow[t]{2}{*}{ Customers Data } & R22 & $\begin{array}{l}\text { Unauthorized parties } \\
\text { access to customer } \\
\text { data }\end{array}$ & $\begin{array}{l}\text { Documented information } \\
\text { management SOP; Information } \\
\text { security SOP }\end{array}$ \\
\hline & & R23 & \begin{tabular}{|l|} 
Employee use \\
customer data for \\
personal interests
\end{tabular} & $\begin{array}{l}\text { Confidentiality of company data } \\
\text { (included customers data) SOP }\end{array}$ \\
\hline E02 & Employees Data & R24 & $\begin{array}{l}\text { Improperly used of } \\
\text { employee data }\end{array}$ & $\begin{array}{l}\text { Confidentiality of company data } \\
\text { (included employees data) SOP }\end{array}$ \\
\hline E03 & Office Furniture & $\mathrm{R} 25$ & $\begin{array}{l}\text { Inventory damage } \\
\text { before age benefits } \\
\text { end }\end{array}$ & Fixed assets damage and loss SOP \\
\hline
\end{tabular}

\subsubsection{Key Performance Indicators}

The learning and growth perspective KPI address the several objectives related to employee development. It is shown in Table 36.
Table 36: Learning and Growth Perspective KPI

\begin{tabular}{|c|c|c|c|}
\hline NO & $\begin{array}{l}\text { STRATEGIC } \\
\text { OBJECTIVES } \\
\end{array}$ & MEASURES & TARGETS \\
\hline 1 & $\begin{array}{l}\text { Employee Satisfaction } \\
\text { and Retention }\end{array}$ & Employee Feedback Amount & Improved \\
\hline 2 & Employee Turn Over & $\begin{array}{l}\text { Number of employees turn-over by } \\
\text { causes }\end{array}$ & Decreased \\
\hline 3 & $\begin{array}{l}\text { Employee Requirement } \\
\text { Matrix }\end{array}$ & $\begin{array}{l}\text { The number of employees that lower } \\
\text { than requirement matrix }\end{array}$ & None \\
\hline 4 & Employee Competency & $\begin{array}{l}\text { Number of employee training and } \\
\text { certifications }\end{array}$ & $\begin{array}{l}\text { Use } 0.25 \% \text { budget from total } \\
\text { company expenses }\end{array}$ \\
\hline 5 & $\begin{array}{l}\text { Organization Vision and } \\
\text { Mission }\end{array}$ & $\begin{array}{l}\text { Refreshment about organization } \\
\text { vision and mission periodically }\end{array}$ & $\begin{array}{l}\text { Employee gathering at least } \\
\text { ones a year, with vision and } \\
\text { mission topics }\end{array}$ \\
\hline 6 & $\begin{array}{l}\text { Standard operating } \\
\text { procedure (SOP) } \\
\text { Evaluation }\end{array}$ & $\begin{array}{ll}1 . & \text { Evaluation of SOP } \\
2 . & \text { Evaluation of Job Description } \\
\text { 3. } & \text { Assessment of Work } \\
& \text { Instruction } \\
\end{array}$ & $\begin{array}{l}\text { Evaluate at least ones a year, } \\
\text { and planning improvement }\end{array}$ \\
\hline 7 & Business Process Model & $\begin{array}{l}\text { Evaluation of Business Process } \\
\text { Model }\end{array}$ & $\begin{array}{l}\text { Evaluate at least ones a year, } \\
\text { and planning improvement }\end{array}$ \\
\hline 8 & $\begin{array}{l}\text { New Technology } \\
\text { Adaptation }\end{array}$ & $\begin{array}{l}\text { 1. Software application development } \\
\text { 2. Office automation development }\end{array}$ & There is improvement \\
\hline
\end{tabular}

\subsection{Five-Year Roadmap}

Here is the roadmap designed for the motorcycle rental business model in 5 (five) years with achievement targets as follows: (see Table 37).

Table 37: Five Years Roadmap

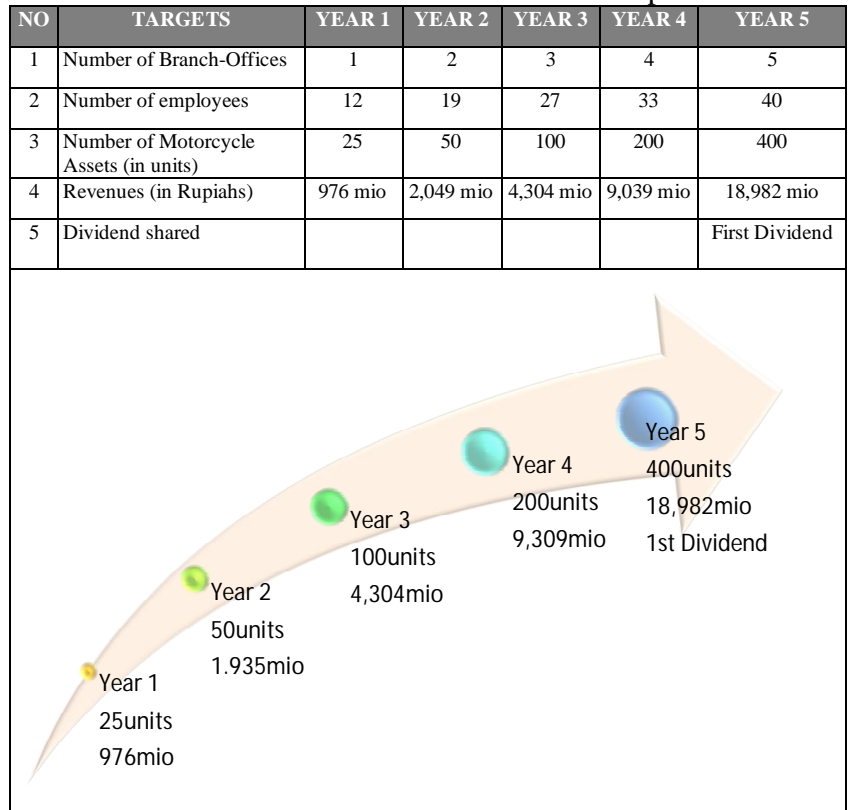

It is expected that the addition of a branch at least 1 (one) location per year to improve customer service and trust. The business model was designed by starting investing 25 (twenty-five) motorcycles, the second year to 50 (fifty) motorcycle rental, in the third years 100 (a hundred) motors, in the fourth year 200 (two hundred) motors, and the fifth year 400 (four hundred) motors. The addition of employees is needed in line with the company's development, but effective and efficient.

Based on the projections in moderate scenarios, the target revenue at 5 (five) years is 976 million rupiahs, 2.049 million rupiahs, 4.304 million rupiahs, 9.039 million rupiahs, and 
18.982 million rupiahs. In the fifth year, expected can be shared the first dividend.

\section{CONCLUSION}

At the assessment of motorcycle rental business model using the four perspectives of the balanced scorecard can be concluded for the following reasons:

1. The business design of this model-based motor vehicle rental can contribute to the company's long-term strategy PT XYZ by:

1. The motorcycle rental business is the existing business supporter of motorcycle dealers and motorcycle workshops.

2. The motorcycle rental business is the main business for PT XYZ forward.

2. Able to provide dividend income and performance improvement for the company PT XYZ as the parent company. So it is expected to support the company's continuity survival.

The author suggests this research can be continued by:

1. Making a standard operating procedure for each activity in the business process, so that the function that runs it gets the correct working standards.

2. At least after a year of running, needs assessments based on the KPI design that has been discussed above, to measure the performance of the company, and to evaluate the created KPIs.

3. At least after a year of running, it is advisable to conduct a risk management assessment and create a risk treatment management based on the findings. By always manage the risk, the success of this business can be maximized.

\section{REFERENCES}

[1] PT Serasi Autoraya, "Sera Member of ASTRA. Annual Report 2017 PT Serasi Autoraya," 2018.

[2] PT Blue Bird Tbk, "2017 Annual Report Perseverance \& Commitment PT Blue Bird Tbk," Jakarta Barat, 2018.

[3] PT Mitra Pinasthika Mustika Tbk, "2017 Annual Report Future Now MPM," Jakarta, 2018.

[4] Express Group, "2017 Consolidation in the Midst of Challengers. Annual Report PT Express Transindo Utama Tbk," 2018.

[5] PT Tunas Ridean Tbk, "Tunas Delivering Happiness Reimaging The Customer Experience 2017 Annual Report," Jakarta Selatan, 2018.

[6] PT Adi Sarana Armanda Tbk, "2017 New Momentum for Sustainable Growth," 2018.

[7] J. Bughin, M. Chui, and J. Manyika, "Clouds, big data, and smart assets: Ten tech-enabled business trends to watch," McKinsey $Q$., no. 4, pp. 1-14,
2010.

[8] A. Muzaki and N. Ray, "Usai Motor Listrik, Viar Buka Sewa Tiga Roda Mulai Rp70 Ribu," Otosia.Com, 11-Feb-2019. [Online]. Available: https://www.otosia.com/berita/usai-motor-listrikviar-buka-sewa-tiga-roda-mulai-rp70-ribu.html.

[9] D. Abdullah and C. I. Erliana, "Bisnis Rental Mobil Melalui Internet (E-Commerce) Menggunakan Algoritma Sha-1 (Sequre Hash Algorithm-1)," J. Speed - Sentra Penelit. Eng. dan Edukasi, vol. 4, no. 2, pp. 38-45, 2012.

[10] L. Yuwono, "Upaya perusahaan rental untuk menyelesaikan wanprestasi dan,” pp. 1-21, 2013.

[11] Erwin and H. Prabowo, "Analisis Pengukuran Kinerja Menggunakan Metode Balanced Scorecard Pada PT.Bahtera Utama," Binus Bus. Rev., vol. 6, no. 2, 2015. https://doi.org/10.21512/bbr.v6i1.1438

[12] R. S. Kaplan and D. P. Norton, "The Balanced Scorecard-Measures That Drive Performance," Harv. Bus. Rev., pp. 71-79, 1991.

[13] S. S. Tyas, “Analisis Strategi Penerapan Teknologi Informasi Dengan Menggunakan Metode SWOT Dan IT Balanced Scorecard (Studi Kasus: PT. Telekomunikasi Indonesia Sub Divisi Satelit)," Bina Nusantara University, 2012.

[14] Z. J. Hannum, "Development of a new technology venture balanced scorecard derived from critical factors that impact product quality," Western Michigan University, 2012.

[15] Mastuki, "IT Balanced Scorecard Implementation To Measure Information Technology Performance On Information Technology Division Of PT.Samudera Indonesia Tbk," Comtech, vol. 6, no. 4, pp. 444-458, 2015. https://doi.org/10.21512/comtech.v6i3.2255

[16] A. S. Baskara, E. R. Kaburuan, L. Ardiansyah, S. Sfenrianto, and T. H. Hwa, "Business Model Canvas of Motorcycle After-Sales Service Mobile Application," Int. J. Civ. Eng. Technol., vol. 10, no. 04, pp. 344-352, 2019.

[17] L. Raju and L. Shastry, "An Advanced Survey on Cloud Storage for Entreprise," Int. J. Adv. Trends Comput. Sci. Eng., vol. 2, no. 5, pp. 35-40, 2013.

[18] V. Goyal, U. S. Pandey, and S. Batra, "Mobile Banking in India: Practices, Challenges and Security Issues," Int. J. Adv. Trends Comput. Sci. Eng., vol. 1, no. 2, pp. 56-66, 2012. 